\title{
Neonatal and Infantile Epilepsy: Acquired and Genetic Models
}

\author{
Aristea S. Galanopoulou ${ }^{1}$ and Solomon L. Moshé ${ }^{1,2}$ \\ ${ }^{1}$ Saul R. Korey Department of Neurology, Dominick P. Purpura Department of Neuroscience, Laboratory \\ of Developmental Epilepsy, Montefiore Medical Center, Albert Einstein College of Medicine, Bronx, \\ New York 10461 \\ ${ }^{2}$ Department of Pediatrics, Montefiore Medical Center, Albert Einstein College of Medicine, Bronx, \\ New York 10461 \\ Correspondence: aristea.galanopoulou@einstein.yu.edu; solomon.moshe@einstein.yu.edu
}

\begin{abstract}
The incidence of seizures and epilepsies is particularly high during the neonatal and infantile periods. We will review selected animal models of early-life epileptic encephalopathies that have addressed the dyscognitive features of frequent interictal spikes, the pathogenesis and treatments of infantile spasms (IS) or Dravet syndrome, disorders with mammalian target of rapamycin (mTOR) dysregulation, and selected early-life epilepsies with genetic defects. Potentially pathogenic mechanisms in these conditions include interneuronopathies in IS or Dravet syndrome and mTOR dysregulation in brain malformations, tuberous sclerosis, and related genetic disorders, or IS of acquired etiology. These models start to generate the first therapeutic drugs, which have been specifically developed in immature animals. However, there are challenges in translating preclinical discoveries into clinically relevant findings. The advances made so far hold promise that the new insights may potentially have curative or disease-modifying potential for many of these devastating conditions.
\end{abstract}

$T^{\mathrm{h}}$ he neonatal and infantile periods show relatively high age-adjusted incidence of epilepsy compared with other ages of life (Hauser et al. 1993). The etiology of newly diagnosed epilepsies at these ages also is distinct, showing greater representation of epilepsies of unknown, genetic, or congenital etiologies (Hauser et al. 1993). The semiology and syndromic phenotypes of epilepsies that first appear in this early life period are also distinct and often more fulminant, appearing with evident neurodevelopmental problems or regression (e.g., epileptic encephalopathies) or characteristic seizure types (e.g., infantile spasms [IS], multifocal clonic seizures) (Table 1). In addition, the treatments for epilepsies of these age groups can be specialized, as is the case with the use of hormonal therapies (e.g., adrenocorticotropic hormone $[\mathrm{ACTH}]$ in certain epileptic encephalopathies). Given the serious repercussions for the development of these neonates and infants and the importance of finding better therapies with disease-modifying potential, several efforts have been made to create animal models of these conditions to increase our understanding and ability to treat them. Here, we will review selected animal models, genetic or induced, that address epilepsies and epileptic encephalopathies characteristic of neonates and infants.

Editors: Gregory L. Holmes and Jeffrey L. Noebels

Additional Perspectives on Epilepsy: The Biology of a Spectrum Disorder available at www.perspectivesinmedicine.org

Copyright (C) 2016 Cold Spring Harbor Laboratory Press; all rights reserved; doi: 10.1101/cshperspect.a022707

Cite this article as Cold Spring Harb Perspect Med 2016;6:a022707 


\section{A.S. Galanopoulou and S.L. Moshé}

Table 1. Animal models of early-life epilepsies and epileptic encephalopathies

\begin{tabular}{|c|c|c|}
\hline Early-life epilepsy syndrome & Known etiologies & Animal models \\
\hline \multicolumn{3}{|l|}{ Epileptic encephalopathies } \\
\hline West syndrome & $\begin{array}{l}\text { Structural metabolic } \\
\text { genetic (multiple) }\end{array}$ & $\begin{array}{l}\text { Acute } \\
\text { NMDA rat model } \\
\text { Prenatal betamethasone/stress, } \\
\text { postnatal NMDA rat model } \\
\text { GBL/Down syndrome mouse } \\
\text { Chronic } \\
\text { TTX rat model } \\
\text { ARX CKO mouse (Arx }{ }^{-/ Y^{-} \text {CKO }} \text { ) } \\
\left.\text { ARX KI mouse (Arx }{ }^{(G C G) 10+7}\right) \\
\text { Multiple-hit rat model }\end{array}$ \\
\hline Lennox-Gastaut syndrome & $\begin{array}{l}\text { Structural metabolic } \\
\text { genetic (multiple) }\end{array}$ & No \\
\hline Ohtahara syndrome & $\begin{array}{l}\text { Structural metabolic } \\
\text { genetic } \\
\text { (ARX, CG1, } \\
\text { STXBP1) }\end{array}$ & $\begin{array}{l}\text { No } \\
\text { Mouse model STXBP1 KO: } \\
\text { no seizure reported yet }\end{array}$ \\
\hline \multirow[t]{2}{*}{ EIEE with suppression burst } & CG1/SLC25A22 & No \\
\hline & STXBP1 & $\begin{array}{c}\text { Mouse model STXBP1 KO: } \\
\text { no seizure reported yet }\end{array}$ \\
\hline Early myoclonic encephalopathy & & No \\
\hline $\begin{array}{l}\text { Dravet syndrome (severe } \\
\text { myoclonic epilepsy) }\end{array}$ & $\begin{array}{l}\text { SCN1A, PCDH19, } \\
\text { GABRG2 }\end{array}$ & $\begin{array}{l}\text { Models of SCN1A or SCN1B } \\
\text { mutations or deletions }\end{array}$ \\
\hline $\begin{array}{l}\text { Myoclonic status in } \\
\text { nonprogressive encephalopathy }\end{array}$ & & No \\
\hline Landau-Kleffner syndrome & $\begin{array}{l}\text { Structural (malformations, } \\
\quad \text { vascular) }\end{array}$ & No \\
\hline Epilepsy with CSWS & $\begin{array}{l}\text { Structural (malformations, } \\
\text { vascular) }\end{array}$ & $\begin{array}{l}\text { No } \\
\text { Electrical stimulation or flurothyl } \\
\text { models of spikes with functional } \\
\text { impairment }\end{array}$ \\
\hline Migrating partial epilepsy & & No \\
\hline Myoclonic astatic epilepsy & Genetic (SCN1A, GABRG2) & No \\
\hline
\end{tabular}

Early-life epilepsies of genetic origin

Benign familial neonatal KCNQ2/3

convulsions

KCNQ2 KI, A306T mouse,

KCNQ3 KI, G311V mouse

Early-life epilepsies, structural/metabolic

Cortical dysplasias

Two-hit models

In utero MAM

In utero irradiation

Focally induced dysplasias

Tish rat

Tuberous sclerosis

Yes

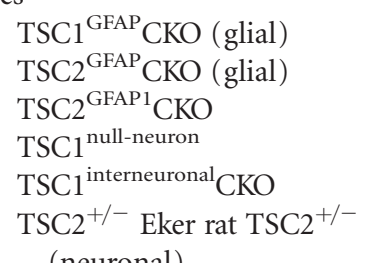

Continued 
Table 1. Continued

\begin{tabular}{lc}
\hline Early-life epilepsy syndrome & Known etiologies \\
\hline & TSC1 $^{\text {Synapsin }}$ CKO \\
& TSC1 $^{\text {DLX5/6 }}$ CKO \\
PTEN-related malformations & Yes \\
Pyridoxine-dependent epilepsy & NS-PTEN, NEX-PTEN, DG-PTEN \\
\hline
\end{tabular}

ARX, Aristaless-related homeobox X-linked; CKO, conditional knockout; CSWS, continuous spikes and waves during slow-wave sleep; EIEE, early-infantile epileptic encephalopathy; GABRG2, $\gamma 2$ subunit of $\mathrm{GABA}_{\mathrm{A}}$ receptors; KCNQ, potassium channel; KO, knockout; MAM, methylazoxymethanol acetate; NMDA, $N$-methyl-D-aspartate; PTEN, phosphatase and tensin homolog; STXBP 1, syntaxin binding protein 1; SCN, sodium channel; TSC, tuberous sclerosis complex; TTX, tetrodotoxin; KI, knockin; GBL, $\gamma$-butyrolactone; TNAP, tissue-nonspecific alkaline phosphatase; Tish, telencephalic internal structural heterotopia.

\section{DEVELOPMENTAL EQUIVALENCY ACROSS SPECIES}

There are many differences across species that make the translation of findings difficult to extrapolate from a rodent that is being born at a premature state of brain development and has a different lifestyle, anatomy, and shorter life span of 2 years to a human organism. In regard to the development of the hypothalamus-pituitarygonadal axis, in most studies, a rodent is considered as neonatal between postnatal (PN) day $0-6$, infantile between PN7-21, juvenile between PN21-32 in females and PN21-35 in males, early pubertal between PN32-36 in females and PN35-45 in males, and young adult on PN60 (Ojeda et al. 1980a,b; Akman et al. 2014). However, across-species comparisons of brain growth, DNA, cholesterol, and water content suggested that PN8-10 rats are more closely related to full-term human newborns (Gottlieb et al. 1977; Dobbing and Sands 1979), although eye opening does not occur until PN13-15 and rodent pups are able to ambulate and run during the third week of life, unlike most infants. In reality, different developmental processes mature at different tempos across species, making definite equivalency rules difficult to generalize (Avishai-Eliner et al. 2002; Galanopoulou and Moshé 2011). In this review, we will mostly refer to models that show epilepsy during the first 3 wk of life (thought of as equivalent to neonatal and infantile age) or have been constructed with the intent to recreate human neonatal and infantile epilepsies.

\section{ANIMAL MODELS OF EPILEPTIC ENCEPHALOPATHIES}

Epileptic encephalopathies are conditions in which "epileptic abnormalities themselves contribute to the progressive disturbance in cerebral function," including "cognitive and behavioral impairments above and beyond what might be expected from the underlying pathology and etiology" (Berg et al. 2010). According to these terminologies, the effects of the epileptic abnormalities (lingering effects of seizures or specific patterns of interictal abnormalities) are dissociated from the effects of the underlying etiologies and concurring treatments, although this is not always easy to document. Neonatal and infantile epileptic encephalopathies are of particular concern because of their dramatic consequences on the neurodevelopmental growth of these infants, as well as their distinct-and not always satisfactory - treatment approaches. In the following sections, we will outline selected animal models in immature rodents that have been designed to model early-life epileptic encephalopathies and discuss their contributions to our current understanding of these conditions.

\section{Animal Studies on the Contribution of Interictal Spikes on Epileptic Encephalopathies}

Early studies on the effects of interictal spikes were conducted on rabbits with focal infusions of either penicillin or bicuculline in the monoc- 
ular area of the visual cortex (PN8-30) to generate chronically focal epileptiform discharges, but not seizures (Chow et al. 1978; Ostrach et al. 1984). This treatment disrupted the appearance of complex and oriented directionaltype cells at the lateral geniculate nucleus. Furthermore, this disruptive effect of the nonictal epileptic activity was age specific as it did not manifest in adult rabbits treated according to these protocols (Baumbach and Chow 1981).

A different approach was adopted by Holmes and colleagues, who exposed adult rats to electrical induction of hippocampal spikes and disrupted the ability of hippocampal place cells to recognize the position of the animal and impaired, therefore, recognition and spatial memory (Shatskikh et al. 2006; Zhou et al. 2007a). Additional studies described that there is a persistent disruption of the hippocampal place cell activity in adult rats exposed to early-life status epilepticus or following flurothyl seizures in adult rats (Holmes and LenckSantini 2006; Zhou et al. 2007b). The investigators describe more pronounced effects when spikes are frequent or widespread and discuss that they may interfere either with awake learning and memory or memory consolidation in slow wave sleep. In a subsequent report, epileptic spikes were induced in immature rats, starting on PN12, using intermittent repetitive flurothyl $\left(\gamma\right.$-aminobutyric acid $[\mathrm{GABA}]_{\mathrm{A}}$ receptor antagonist) exposure (four daily 2-h sessions for $10 \mathrm{~d}$ ) (Khan et al. 2010). Long-lasting deficits in reference memory and long-term potentiation were observed in adulthood.

\section{Animal Models of Epileptic/IS and West Syndrome}

West syndrome (WS) is the first recognized epileptic encephalopathy, described by W.J. West in 1841 (West 1841; Capovilla et al. 2013). WS is an age-specific epileptic encephalopathy, which typically begins in infants, usually the first year of life, although late-onset WS has been described. WS usually manifests with characteristic epileptic seizures (IS, chaotic, highamplitude, and multifocally epileptic interictal electroencephalography [EEG] background [hypsarrhythmia]), and, often, neurodevelopmental arrest or regression. IS are motor seizures consisting of sudden flexion of extension of axial musculature and limbs, often in clusters.

WS can be a result of a wide range of etiologies, including structural or metabolic lesions (malformations, vascular, inflammatory or immune, hypoxic, etc.), genetic, or others yet unknown (Frost and Hrachovy 2005; Berg et al. 2010; Osborne et al. 2010; Pellock et al. 2010; Paciorkowski et al. 2011b; Epi4K Consortium et al. 2013). The estimated incidence of WS is low, occurring in one out of 3-5000 live births, but its consequences are grave. Depending on the underlying etiology, the majority of infants remain with cognitive or neurodevelopmental deficits ( $\sim 50 \%-60 \%$ of infants with IS of unknown etiology; $84 \%-98 \%$ of infants with IS caused by structural/metabolic etiology) or persisting epilepsy, which is usually drug resistant (Baram et al. 1996; Karvelas et al. 2009; Pellock et al. 2010; Auvin et al. 2012; Vendrame et al. 2012; Lee et al. 2013).

The first line of treatment choices includes hormonal therapy (ACTH and/or high-dose glucocorticoids) and the GABA aminotransferase inhibitor vigabatrin (Baram et al. 1996; Mackay et al. 2004; Pellock et al. 2010; Go et al. 2012). These treatments may stop IS in $60 \%-90 \%$ of cases, depending on etiology, but they do not necessarily prevent recurrences or persistence of other epileptic seizures or neurodevelopmental deficits. In WS of unknown etiology (old cryptogenic category), early cessation of spasms with hormonal therapy has been shown to partially improve neurodevelopmental outcomes (Riikonen 1982; Lombroso 1983; Kivity et al. 2004; Lux et al. 2005; Lux and Osborne 2006; Cohen-Sadan et al. 2009; Darke et al. 2010; O'Callaghan et al. 2011), although no difference in outcome was reported in a different study (Mohamed et al. 2011). The need for more effective and better-tolerated therapies with rapid onset of action is evident, including infants with IS caused by structural/metabolic etiologies who have poorer prognosis and treatment response.

Interestingly, there are currently no reports on IS in animals that are under veterinarian 
care. To be able to study the pathogenic mechanisms of IS and develop new treatments, it was therefore necessary to develop animal models of IS (Table 2). Given the etiologic heterogeneity, different approaches have been used for epileptic spasms, either genetic manipulations or chemical induction. Acute models result in transient appearance of epileptic spasms postinduction, whereas chronic models manifest an evolving chronic phenotype (Table 2 ). Here, we will present the main features of these models, as well as those of the corticotropin-releasing hormone $(\mathrm{CRH})$ model of seizures because of its affinity to the stress hypothesis of IS, which has been discussed as a possible mechanism of the ACTH effect.

\section{CRH Rat Model and the Stress Theory of IS}

The in vivo proconvulsant effects of $\mathrm{CRH}$ had been shown early on by intracerebroventricular injections in adult rats (Ehlers et al. 1983; Weiss et al. 1986). The beneficial effects of ACTH in treating spasms led to an investigation into the involvement of hormones of the hypothalamus-pituitary-adrenal axis (HPA) in the pathogenesis of IS. Baram hypothesized that massive IS may be a result of exaggerated responsiveness of the HPA axis to stressors during an early period of development when there are increased levels of unoccupied CRH receptors, which could therefore be overactivated by excess release of CRH (Insel et al. 1988; Baram 1993). However, no significant differences in the levels of $\mathrm{CRH}$ were found in the cerebrospinal fluid (CSF) of infants with IS (Baram et al. 1992), although intracerebral injection of $\mathrm{CRH}$ produced limbic seizures (jaw myoclonus, focal limb extension, and clonus), which respond to phenytoin, but not to porcine $\mathrm{ACTH}_{1-39}$ (Baram and Schultz 1995) or spasms.

\section{N-methyl-D-Aspartate (NMDA) Rat Model (Acute)}

A developmental study into the effects of the known proconvulsant glutamatergic agonist NMDA ( $N$-methyl-D-aspartate), given intraperitoneally, revealed a predilection to trigger generalized tonic flexion-type seizures with a loss of righting reflex only in immature pups (18 d or younger), which the investigators described as "emprosthotonic" (Mares and Velisek 1992). Other behaviors and seizure types were also elicited (hyperactivity, tail twisting, clonic-tonic seizures) during the acute postinjection period, which has also been described as NMDA-induced status epilepticus (Stafstrom and Sasaki-Adams 2003).

In the initial report (Mares and Velisek 1992), the EEG was characterized by electrographic suppression and poor electroclinical correlation with spasms; however, subsequent studies using lower NMDA doses reported temporal correlation of electrodecremental responses (EDRs) with spasms (Velisek et al. 2007). [ $\left.{ }^{14} \mathrm{C}\right] 2$-deoxyglucose uptake studies showed increased uptake in limbic, hypothalamic, and brainstem regions (Velisek et al. 2007). Initially, NMDA-induced flexion spasms were not affected by $\mathrm{ACTH}_{1-24}$ or rat $\mathrm{ACTH}_{1-39}$ pretreatment (Velisek et al. 2007), but subsequent studies showed reduction in spasms with high doses of porcine $\mathrm{ACTH}_{1-39}$ (Table 3) (Wang et al. 2012). Interestingly, the effect of $\mathrm{ACTH}_{1-39}$ was observed even in adrenalectomized rats, possibly suggesting that it does not strictly depend on the release of adrenal steroids (Wang et al. 2012). Vigabatrin pretreatment also decreased spasms in this model (Kubova and Mares 2010). Extensive testing with other available drugs showed deterioration of spasms with hydrocortisone, no or modest effect with different doses of valproic acid, spasm reduction, but increase in epileptiform activity with pyridoxine, and no effect with clonazepam (Velisek and Mares 1995; Kabova et al. 1999; Kubova and Mares 2010). In adulthood, these rats show slower performance in the Morris water maze, but they were able to learn, and show increased susceptibility to pentylenetetrazole seizures, although no spontaneous seizures have been reported (Stafstrom and Sasaki-Adams 2003).

Overall, the NMDA model has provided evidence for NMDA receptor involvement in the expression of tonic flexion seizures, but also indicates that overactivation of NMDA receptors on its own is not sufficient to reproduce the chronic phenotype of WS. 
A.S. Galanopoulou and S.L. Moshé
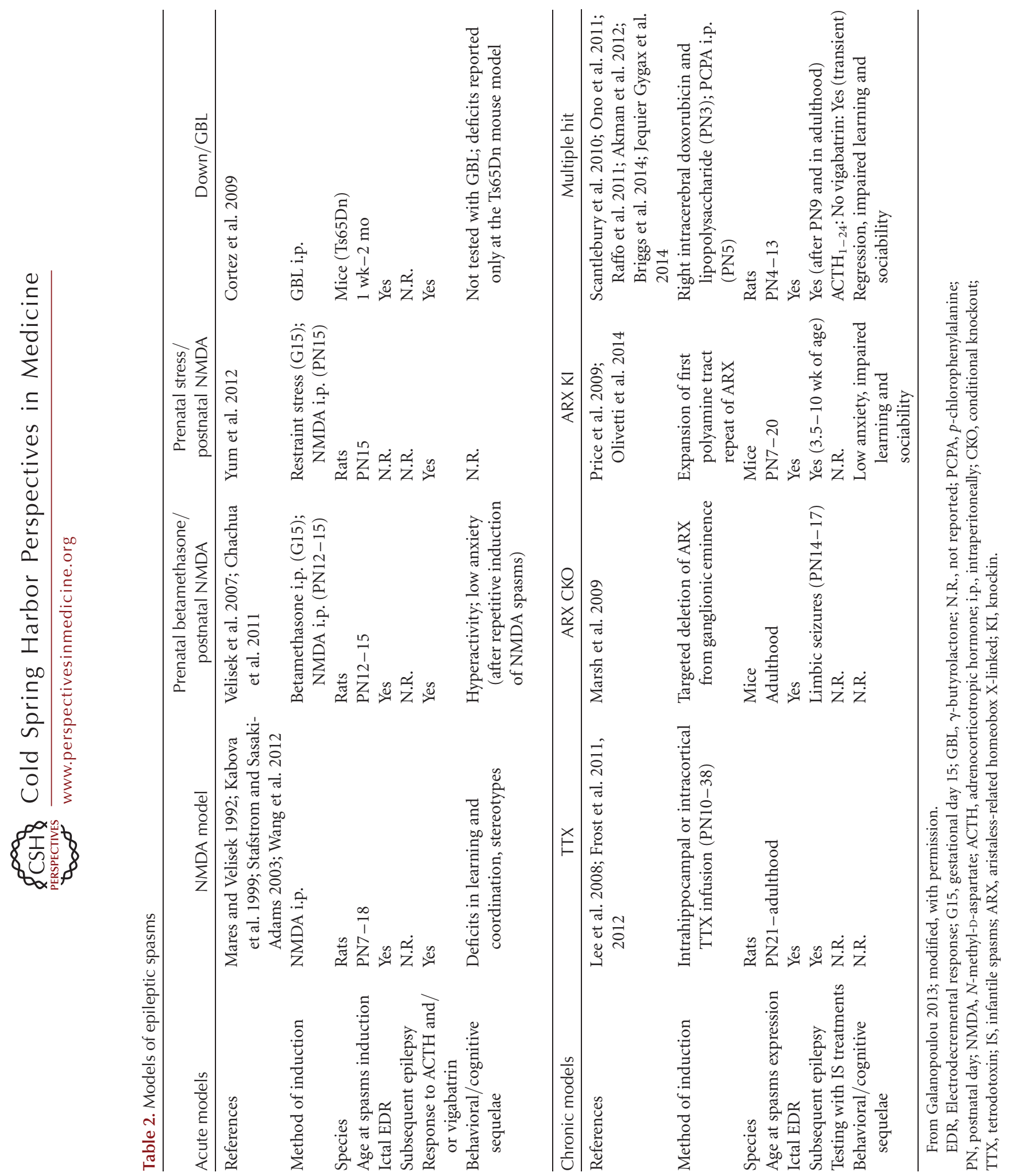
Table 3. Preclinical drug testing in models of epileptic spasms

\begin{tabular}{|c|c|c|c|c|}
\hline Acute models & NMDA model & $\begin{array}{c}\text { Prenatal } \\
\text { betamethasone/ } \\
\text { postnatal NMDA }\end{array}$ & $\begin{array}{c}\text { Prenatal stress/ } \\
\text { postnatal NMDA }\end{array}$ & Down/GBL \\
\hline $\mathrm{ACTH}_{1-24}$ & $\begin{array}{l}\text { No effect on latency } \\
\quad(0.1-0.4 \mathrm{mg} / \mathrm{kg} \text { i.p.) } \\
\text { (Velisek et al. 2007) }\end{array}$ & & & $\begin{array}{c}\text { Shortens EDR (40, } \\
80 \mu \mathrm{g} / \text { mouse) } \\
\text { (Cortez et al. } 2009)\end{array}$ \\
\hline $\begin{array}{l}\mathrm{ACTH}_{1-39}(\text { rat } \\
\text { synthetic) }\end{array}$ & $\begin{array}{l}\text { No effect on latency } \\
\quad(0.1 \mathrm{mg} / \mathrm{kg} \text { i.p. }) \\
\text { (Velisek et al. } 2007)\end{array}$ & $\begin{array}{l}\text { Delays spasms } \\
\qquad(0.1 \mathrm{mg} / \mathrm{kg} \text { i.p. }) \\
\quad \text { (Velisek et al. 2007) }\end{array}$ & $\begin{array}{l}\text { No effect with } \\
\text { single dose; } \\
\text { delay and } \\
\text { reduction of } \\
\text { spasms after } \\
\text { nine doses } \\
(0.3 \mathrm{mg} / \mathrm{kg} / \\
\text { dose, three } \\
\text { doses } / \text { day s.c.) } \\
\text { (Yum et al. } \\
\text { 2012) }\end{array}$ & \\
\hline $\begin{array}{l}\mathrm{ACTH}_{1-39} \\
\text { (porcine, } \\
\text { natural) }\end{array}$ & $\begin{array}{l}\text { Delays and reduces } \\
\text { spasms severity } \\
\text { (100 U/kg ACTH } \\
\text { i.p.) (Wang et al. } \\
\text { 2012) }\end{array}$ & & & $\begin{array}{l}\text { No effect on EDR } \\
\text { duration (20- } \\
80 \mu \mathrm{g} / \text { mouse) } \\
\text { (Cortez et al. 2009) }\end{array}$ \\
\hline Hydrocortisone & $\begin{array}{l}\text { Increases spasms (10- } \\
25 \mathrm{mg} / \mathrm{kg})(\text { Kabova } \\
\text { et al. 1999) }\end{array}$ & & & \\
\hline $\begin{array}{l}\text { Methyl- } \\
\text { prednisolone }\end{array}$ & & $\begin{array}{l}\text { Repetitive, but no } \\
\text { single dose reduces } \\
\text { spasms incidence } \\
(60 \mathrm{mg} / \mathrm{kg}) \\
\text { (Chachua et al. } \\
2011)\end{array}$ & & \\
\hline Vigabatrin & $\begin{array}{l}\text { Decreased spasms } \\
\text { incidence }(600- \\
1200 \mathrm{mg} / \mathrm{kg}) \\
\text { (Kubova and Mares } \\
\text { 2010) }\end{array}$ & $\begin{array}{l}\text { Decreases spasms } \\
\text { incidence } \\
(250 \mathrm{mg} / \mathrm{kg}) \\
\text { (Chachua et al. } \\
\text { 2011) }\end{array}$ & & $\begin{array}{l}\text { Shortens EDR } \\
\qquad \begin{array}{l}(250-500 \mathrm{mg} / \mathrm{kg}) \\
\quad(\text { Cortez et al. 2009) }\end{array}\end{array}$ \\
\hline Pyridoxine (B6) & $\begin{array}{l}\text { Decreases spasms } \\
\text { incidence; induces } \\
\text { epileptiform activity } \\
(250 \mathrm{mg} / \mathrm{kg}) \\
\text { (Kabova et al. 1999) }\end{array}$ & & & \\
\hline Clonazepam & $\begin{array}{l}\text { No effect }(0.2-1 \mathrm{mg} / \\
\mathrm{kg}) \text { (Velisek and } \\
\text { Mares 1995) }\end{array}$ & & & \\
\hline Valproic acid & $\begin{array}{l}\text { No effect } \\
\quad(100-400 \mathrm{mg} / \mathrm{kg}) \\
\quad(\text { Kubova and Mares } \\
\text { 2010) } \\
\text { Modest effect (Kabova } \\
\quad \text { et al. 1999) }\end{array}$ & & & $\begin{array}{l}\text { Shortens EDR } \\
\qquad(100-400 \mathrm{mg} / \mathrm{kg}) \\
\quad(\text { Cortez et al. 2009) }\end{array}$ \\
\hline
\end{tabular}


A.S. Galanopoulou and S.L. Moshé

Table 3. Continued

\begin{tabular}{|c|c|c|c|c|}
\hline Acute models & NMDA model & $\begin{array}{c}\text { Prenatal } \\
\text { betamethasone/ } \\
\text { postnatal NMDA }\end{array}$ & $\begin{array}{c}\text { Prenatal stress/ } \\
\text { postnatal NMDA }\end{array}$ & Down/GBL \\
\hline Ethosuximide & & & & $\begin{array}{l}\text { Shortens EDR } \\
\qquad(25-50 \mathrm{mg} / \mathrm{kg}) \\
\quad(\text { Cortez et al. 2009) }\end{array}$ \\
\hline CGP 35348 & & & & $\begin{array}{l}\text { Shortens EDR } \\
\qquad(50-200 \mathrm{mg} / \mathrm{kg}) \\
\quad(\text { Cortez et al. 2009) }\end{array}$ \\
\hline Baclofen & & & & $\begin{array}{l}\text { Prolongs EDR } \\
\qquad(0.5-2 \mathrm{mg} / \mathrm{kg}) \\
\quad(\text { Cortez et al. 2009) }\end{array}$ \\
\hline $\begin{array}{l}\text { 5-Hydroxy- } \\
\text { tryptophan }\end{array}$ & & & & $\begin{array}{l}\text { Prolongs EDR } \\
\qquad(100-150 \mathrm{mg} / \mathrm{kg}) \\
\quad(\text { Cortez et al. 2009) }\end{array}$ \\
\hline Rapamycin & & $\begin{array}{l}\text { No acute effect with } \\
\text { low doses ( } 3 \mathrm{mg} / \\
\text { kg i.p.) (Chachua } \\
\text { et al. 2011) }\end{array}$ & & \\
\hline
\end{tabular}

Prenatal Betamethasone or Perinatal Stress/Postnatal NMDA Rat Models (Acute)

These modifications of the NMDA model are hybrids between the stress/HPA theory of IS and NMDA models. The first model includes prenatal administration of betamethasone at gestational day 15 (G15), which is expected to disrupt the HPA axis, followed by administration of NMDA on PN15 (Velisek et al. 2007). As a result, NMDA spasms in G15-betamethasone primed rats occur in higher spasm counts and become sensitive to synthetic rat $\mathrm{ACTH}_{1-39}$ under dosing conditions that had failed to control NMDA spasms (Table 3) (Velisek et al. 2007). Similarly, forced restraint in G15 pregnant female rats increases the severity of NMDA spasms in their offspring and renders them sensitive to repetitive administration of synthetic rat $\mathrm{ACTH}_{1-39}$, as these rats had lower weights, but also less spasms (Yum et al. 2012). A third modification was cited by Shi et al. (2012), who report that prenatal forced cold swim and postnatal NMDA spasms were associated with less cortisol and ACTH levels in the offspring (Shi et al. 2012). Finally, postnatal adrenalectomy on PN11 increases the severity of NMDA spasms on PN15 (Wang et al. 2012).

In brief, these perinatal stress/postnatal NMDA models lend support to the hypothesis that HPA dysfunction and/or prior perinatal stressors have lasting effects that aggravate NMDA, and these lasting effects can be partially corrected by repeat high doses of synthetic rat $\mathrm{ACTH}_{1-39}$. Following the testing of the mammalian target of rapamycin (mTOR) inhibitor rapamycin in the multiple-hit rat model, which will be discussed later on, the drug was also tested in the prenatal betamethasone/postnatal NMDA model (Chachua et al. 2011). Administration of low doses of rapamycin given either $1 \mathrm{~d}$ or for $8 \mathrm{~d}$ before the NMDA injection had no effect on NMDA-induced spasms. The lack of effect is partially anticipated by the results in the multiple-hit model that showed acute effects on spasms with the high, but not the low, doses of rapamycin. However, further comparisons among the models are hindered by the different age groups and induction models, and by the fact that the effects of rapamycin on a normal 
brain with normal-for-age mTOR activity can be completely different from its effects on a diseased brain with pathologic overactivation of mTOR (Raffo et al. 2011).

\section{$\gamma$-Butyrolactone/Down Syndrome Mouse Model (Acute)}

Among infants with Down syndrome, 1.5\%$32 \%$ have IS (Romano et al. 1990; Pueschel et al. 1991; Goldberg-Stern et al. 2001; Sanmaneechai et al. 2013). Using a mouse model of Down syndrome (Ts65Dn mouse), Cortez and colleagues report that administration of $\gamma$ butyrolactone $(\mathrm{GBL})$, a prodrug of the $\mathrm{GABA}_{\mathrm{B}}$ receptor agonist $\gamma$-hydroxybutyrate, triggers facial myoclonus. Vibrissal twitching, followed by extensor spasms, are associated by bursts of polyspikes and EDRs (Cortez et al. 2009). These events were elicited acutely in 1-wk- to at least 2-mo-old mice (i.e., young adults) and responded to rat $\mathrm{ACTH}_{1-24}$, but not to porcine $\mathrm{ACTH}_{1-39}$, and to vigabatrin (Table 3 ). In addition, these extensor spasms responded to valproate, $\mathrm{GABA}_{\mathrm{B}}$ receptor antagonist CGP 35,348, ethosuximide, and worsened with 5-hydroxytryptophan, reminiscent of the clinical report of IS in infants with Down syndrome who were given this drug (Coleman 1971).

This model introduced the possible involvement of $\mathrm{GABA}_{\mathrm{B}}$ receptors in the expression of IS in Down syndrome and also supported the proposed pathogenic role of serotoninergic pathways in IS because of Down syndrome. However, no long-term epilepsy or other cognitive or behavioral abnormalities specifically attributed to the GBL-induced spasms or 5-hydroxytryptophan have been reported yet.

\section{Tetrodototoxin Rat Model of Hypsarrhythmia (Chronic)}

According to the theory of developmental desynchronization proposed by Frost and Hrachovy (2005), IS are a consequence of asynchronous development of the brain caused by various genetic, structural, or metabolic etiologies. To achieve this experimentally, focal long-term infusions of tetrodotoxin, a sodium channel blocker, were given in the right hippo- campus or cerebral cortex of PN10-12 rats for up to $4 \mathrm{wk}$ (Lee et al. 2008). The result was seizures that resembled spasms with EDRs, first seen around PN21 and lasting until adulthood. Other seizures are also observed. Although the age when these tetrodotoxin (TTX) spasms first appear is equivalent to juvenile rather than infantile age, the advantage of recording EEG from older animals allowed a more extensive electrographic coverage of the skull and documentation of interictal patterns, which resemble hypsarrhythmia. Spectral analysis shows high-frequency EEG activity from multifocal areas ictally and interictally, which are usually more intense, contralateral to the infusion site (Frost et al. 2011, 2012). This model also highlights the principle that focal neocortical lesions may produce IS and hypsarrhythmia, lending support to the notion that IS could be classified under either focal or generalized seizures (Berg et al. 2010). At present, there are no published reports on the response of these TTX spasms and hypsarrhythmia to any of the currently used treatments for IS.

\section{Aristaless-Related Homeobox X-Linked Genetic Mouse Models (Chronic) and Interneuronopathies}

Aristaless-related homeobox X-linked (ARX) is a transcriptional factor involved in ventral telencephalon morphogenesis, migration of GABAergic neuronal progenitors, and early commitment of cholinergic neurons (Friocourt and Parnavelas 2010). It has been linked with different early-life epilepsies, including Ohtahara syndrome and WS. The reports of patients with IS include both infants with no identifiable structural brain abnormality (which would have otherwise been classified as unknown etiology) and infants with pronounced abnormalities, such as X-linked lissencephaly with abnormal genitalia (XLAG) (Dobyns et al. 1999; Scheffer et al. 2002; Stromme et al. 2002; Kato et al. 2003, 2007; Kato 2006; Paciorkowski et al. 2011a).

Eight Arx genetic mouse models have been generated and most of them were reviewed in detail in Olivetti and Noebels (2012). A common pathologic finding in most of these mice 
has been the presence of interneuronopathy, meaning deficient and/or malformed interneurons, which is reported in six of the eight existing ARX mouse models (Kitamura et al. 2002, 2009; Marsh et al. 2009; Price et al. 2009), whereas in the other two $\left(\operatorname{Arx}^{(\mathrm{GCG}) 7 / \mathrm{Y}} ; \operatorname{Arx}^{-/ \mathrm{Y}}\right.$ $\mathrm{Emx1}{ }^{\mathrm{Cre}}$ ), interneurons appear intact (Beguin et al. 2013; Simonet et al. 2014). Epilepsy has been reported in only three of these models $\left(\operatorname{Arx}^{-/ \mathrm{Y} \mathrm{CKO}}, \operatorname{Arx}^{(\mathrm{GCG}) 7}, \operatorname{Arx}^{(\mathrm{GCG}) 10+7}\right)$, which also have interneuronopathy, whereas spasms were seen only in two of these ( $\mathrm{Arx}^{-/ \mathrm{Y} \text { CKO }}$ $\operatorname{Arx}^{(\mathrm{GCG}) 10+7}$ ). Conditional knockout (CKO) of Arx in selected populations of neurons results in epilepsy with spasms when median ganglionic eminence progenitors are targeted, impairing GABAergic interneuronal migration $\left(\mathrm{Arx}^{-/ \mathrm{Y} \mathrm{CKO}}\right)$, but not when dorsal telencephalic neurons are targeted, leaving interneurons intact $\left(\mathrm{Arx}^{-/ \mathrm{Y}} \mathrm{Emxl}^{\mathrm{Cre}}\right)$ (Marsh et al. 2009; Simonet et al. 2014). In contrast, $\mathrm{Arx}^{-/ \mathrm{Y}} \mathrm{Emxl}^{\mathrm{Cre}}$ mice have prominent cognitive and behavioral deficits. These findings indicate that cellular specification of the genetic deficits is critical for the epilepsy (e.g., interneuronopathies) versus cognitive (e.g., dorsal forebrain neurons) phenotype.

Among the strains that show spasms, the $\mathrm{ARX}^{-/ \mathrm{Y}} \mathrm{CKO}$ mouse model manifests stage 5 seizures, but not spasms, between PN14-17, whereas spasms, freezing events, and stage 5 seizures appear in adulthood (Marsh et al. 2009). Although the appearance of spasms seems to have lost its expected age specificity, it should be noted that the early video-EEG studies were very brief in this study ( $24 \mathrm{~h}$ only) because of the technical limitation of monitoring immature mice. Histologically, decreased numbers of calbindin and calretinin neurons were seen in the cerebral cortex.

In parallel, Price et al. constructed a knockin (KI) mouse bearing an extension of the first polyalanine repeat of $\operatorname{Arx}\left(\operatorname{Arx}{ }^{(\mathrm{GCG}) 10+7}\right)$, similar to a clinically relevant genetic defect (Poirier et al. 2008; Price et al. 2009). The investigators describe a loss of function of the Arx protein, caused by mistargeting to the cytoplasm, which results in reduced numbers of calbindin cortical, hippocampal, and striatal interneurons, as well as neuropeptide Y (NPY) and cholinergic interneurons in the striatum (Price et al. 2009). These mice develop an interesting phenotype that consists of spasms during the second and third weeks of life, behavioral arrests after PN14, and generalized seizures after PN19. In addition, mice have low anxiety, impaired associative learning, and abnormal social interactions.

Based on existing reports that estradiol may promote cell proliferation, neuronal migration, and differentiation (McCarthy 2008), a follow-up study investigated the therapeutic effects of neonatal estradiol administration in the Arx ${ }^{(G C G) 10+7}$ mouse (Table 4) (Olivetti et al. 2014). Neonatal estradiol administration before the onset of spasms (PN3-10) restored the number of calbindin and NPY interneurons in the cerebral cortex, as well as cholinergic striatal neurons, and prevented spasms and subsequent epilepsy in their model. In contrast, late administration of estradiol after spasms and other seizures occurred (PN33-40) had no effect.

These studies exemplify the value of transgenic mice in understanding the pathophysiology of and designing specific personalized therapies for genetic etiology epilepsy syndromes. The Arx mice supported the proposed role of interneuronopathy in the associated epilepsies (Kato and Dobyns 2005) and underline the importance of cellular specification of the genetic defects in defining the final epilepsy or cognitive phenotype. However, they also indicate that additional factors may be involved in modifying the outcomes because not all mice with interneuronopathy manifest epilepsy. Yet, several questions remain unanswered. Can these gene-tailored therapies be extended to IS of different etiology? Currently, initiation of the treatment before the onset of symptoms or precipitating insult is not clinically relevant in cases of WS because of unknown or acquired etiologies. However, the results in the ARX model highlight the importance of exploring presymptomatic treatments in WS of genetic etiologies, in which disease onset may precede the onset of symptoms. Still, in infants with similar Arx defects, what is the equivalent sensitive period for therapies like neonatal estradiol and what would the optimal treatment protocol be? 
Table 4. Preclinical drug testing studies in the chronic models

\begin{tabular}{|c|c|c|c|}
\hline Drug & Protocol & Drug effect & References \\
\hline \multicolumn{4}{|c|}{ Multiple-hit rat model (treatments tested after onset of spasms) } \\
\hline $\mathrm{ACTH}_{1-24}$ & $\begin{array}{l}0.0125 \mathrm{mg} / \mathrm{kg} / \text { day i.p., } \\
\text { PN4-13 }\end{array}$ & No effect on spasms & $\begin{array}{l}\text { Scantlebury } \\
\text { et al. } 2010\end{array}$ \\
\hline $\begin{array}{l}\text { Vigabatrin (GABA } \\
\text { aminotransferase } \\
\text { inactivator) }\end{array}$ & $\begin{array}{l}10-20 \mathrm{mg} / \mathrm{kg} \text { i.p. twice } \\
\text { daily, starting on PN4 }\end{array}$ & $\begin{array}{l}\text { Transient suppression of spasms on } \\
\text { PN5; higher doses were not tolerated }\end{array}$ & $\begin{array}{l}\text { Scantlebury } \\
\text { et al. } 2010\end{array}$ \\
\hline $\begin{array}{l}\text { CPP-115 (high affinity } \\
\text { vigabatrin analog) }\end{array}$ & $\begin{array}{l}\text { Single or daily } \\
\text { administration, starting } \\
\text { on PN4;0.1-1 mg/kg } \\
\text { i.p. }\end{array}$ & $\begin{array}{l}\text { Reduces spasms (PN5-7), no effect on } \\
\text { learning or neurodevelopmental } \\
\text { milestones, good tolerability } \\
\text { Rapid onset effect on spasms on } \\
\text { PN6-7 }\end{array}$ & $\begin{array}{l}\text { Briggs et al. } \\
2014\end{array}$ \\
\hline Phenytoin & $\begin{array}{l}\text { Single injection (PN4); } \\
\quad 20-50 \mathrm{mg} / \mathrm{kg} \text { i.p. }\end{array}$ & No effect on spasms & Ono et al. 2011 \\
\hline \multirow[t]{4}{*}{$\begin{array}{l}\text { Rapamycin (mTOR } \\
\text { inhibitor) }\end{array}$} & $1-3 \mathrm{mg} / \mathrm{kg}$ i.p. (PN4-12) & $\begin{array}{l}\text { No acute but delayed effect on } \\
\text { spasms only }\end{array}$ & $\begin{array}{l}\text { Raffo et al. } \\
\quad 2011\end{array}$ \\
\hline & $\begin{array}{l}\text { Pulse protocol (i.p.): PN4: } \\
6 \mathrm{mg} / \mathrm{kg} ; \text { PN5: } 3 \mathrm{mg} / \\
\text { kg; PN6: } 3 \mathrm{mg} / \mathrm{kg}\end{array}$ & $\begin{array}{l}\text { Rapid-onset reduction of spasms; stops } \\
\text { spasms and improves Barnes maze } \\
\text { performance (PN16-19) }\end{array}$ & \\
\hline & & No effect on other seizures until PN20 & \\
\hline & & $\begin{array}{l}\text { Transient loss of weight during } \\
\text { treatment period }\end{array}$ & \\
\hline Carisbamate $^{\mathrm{a}}$ & $\begin{array}{l}\text { Single injection (PN4 or } \\
\text { PN6-7); 30-60 mg/kg } \\
\text { i.p. }\end{array}$ & Acute suppression of spasms & Ono et al. 2011 \\
\hline $\begin{array}{l}\text { NAX } 5055 \text { (galanin } \\
\text { receptor } 1 \text { preferring } \\
\text { agonist) }\end{array}$ & $\begin{array}{l}\text { Single injection (PN4); } \\
\quad 0.5-4 \mathrm{mg} / \mathrm{kg} \text { i.p. }\end{array}$ & $\begin{array}{l}\text { No effect on spasms; low expression } \\
\text { of Galanin receptor } 1\end{array}$ & $\begin{array}{l}\text { Jequier Gygax } \\
\text { et al. } 2014\end{array}$ \\
\hline \multicolumn{4}{|c|}{ ARX KI mouse model (treatment tested before onset of spasms) } \\
\hline Estradiol & 40 ng/g s.c., PN3-10 & $\begin{array}{l}\text { Prevents spasms and epilepsy, } \\
\text { restores interneuronal population } \\
\text { in cerebral cortex } \\
\text { PN33-40 treatment has no effect }\end{array}$ & $\begin{array}{l}\text { Olivetti et al. } \\
2014\end{array}$ \\
\hline
\end{tabular}

From Galanopoulou and Moshé 2015; modified, with permission, from Elsevier.

ACTH, adrenocorticotropic hormone; i.p., intraperitoneal; s.c., subcutaneous; PN, postnatal day; GABA, $\gamma$-aminobutyric acid; CPP-115, Catalyst Pharmaceutical Partners, Coral Gables, FL; mTOR, mammalian target of rapamycin.

${ }^{\text {a } T h e s e ~ d r u g s ~ h a v e ~ a c q u i r e d ~ o r p h a n ~ d r u g ~ i n d i c a t i o n ~ f o r ~ i n f a n t i l e ~ s p a s m s ~ b y ~ t h e ~ F e d e r a l ~ D r u g ~ A d m i n i s t r a t i o n ~(F D A) . ~}$

\section{The Multiple-Hit Rat Model of IS Caused by Structural Lesion}

IS caused by structural lesions have the poorest prognosis and response to treatment, and the majority remain with neurodevelopmental deficits and drug-resistant epilepsies. Although the exact networks implicated in IS are not yet known, functional or structural impairment of cortical and/or subcortical structures or their connections are thought to be involved (Lado and Moshé 2002). To generate a rat model of these more refractory forms of IS, a combination of cytotoxic injury and disruption of the white matter connections was attempted with a combination of right intracerebroventricular doxorubicin and right intracortical lipopolysaccharide given on PN3. In addition, $p$-chlorophenylalanine (PCPA: tryptophan hydroxylase irreversible inhibitor; serotonin depletor) was given on PN5 (Scantlebury et al. 2010), based on reports of disrupted serotonin metabolism 
in infants with IS (Silverstein and Johnston 1984). The underlying pathology involves right hemispheric injury in the peri-infusional cortical region, right hippocampus, and periventricular area (Briggs et al. 2014; Jequier Gygax et al. 2014). Interestingly, there is also a significant layer-specific reduction in parvalbumin-positive GABAergic interneurons in the contralateral to the lesion cerebral cortex, and many of the remaining interneurons show abnormal morphology, suggestive of an acquired interneuronopathy (Galanopoulou 2013). Extensive monitoring of these pups revealed clusters of spasms already from PN4, indicating that PCPA is not necessary for the induction of spasms, although it exacerbates the frequency of spasms. Spasms are observed between PN4-13, whereas additional types of seizures manifest from PN9: behavioral arrest, episodes of restlessness with loss of righting, or limbic-type seizures (Scantlebury et al. 2010; Raffo et al. 2011). Although PN4-13 rats are usually considered as equivalent to premature or full-term neonates, this is the time when motor milestones mature in the rat and are equivalent to human infants, as shown by the gradual improvement in their ability to ambulate (open field activity) (Scantlebury et al. 2010). We consider this of special relevance to IS, which are predominantly motor seizures manifesting, usually, at a developmental stage when the ability to ambulate is being acquired. In addition, learning deficits have been documented after the resolution of spasms (PN16-19), which are partly a result of the underlying lesion, but can also be partially reversed by appropriate therapies (Raffo et al. 2011). More recently, spontaneous motor seizures were documented in adulthood (Akman et al. 2012).

Consistent with the more refractory course of IS caused by structural lesions in humans, spasms in this model do not respond to synthetic $\mathrm{ACTH}_{1-24}(0.0125 \mathrm{mg} / \mathrm{kg} /$ day i.p. [intraperitoneally], PN4-13), but transiently respond to vigabatrin (Scantlebury et al. 2010), whereas, appropriately for IS, do not respond to phenytoin (Table 4) (Ono et al. 2011). Further confirming the responsiveness to vigabatrin, a recently developed high-affinity inactivator of GABA aminotransferase, CPP-115 (Catalyst Pharmaceutical Partners, Coral Gables, FL), which shows lower than vigabatrin risk for retinal toxicity in animal studies (Pan et al. 2012; Silverman 2012), showed better efficacy/tolerability profile in the multiple-hit model (Briggs et al. 2014).

The multiple-hit model has been used extensively to screen for new therapies for IS with rapid onset effects on spasms and disease-modifying potential. Significant interest was drawn toward targeting the mTOR pathway, given the association of several disorders of the mTOR pathway with IS. The classical genetic cause of mTOR overactivation, tuberous sclerosis, is diagnosed in $5 \%-10 \%$ of infants with IS, and $38 \%$ of infants with tuberous sclerosis have IS (Sidenvall and Eeg-Olofsson 1995; Curatolo et al. 2001; Riikonen 2001; Karvelas et al. 2009; Bombardieri et al. 2010; Chu-Shore et al. 2010; Osborne et al. 2010). Mutations in pathways that cross talk and increase the activity of mTOR have been identified in patients with IS as a result of hemimegalencephaly or polyhydramnios, microcephaly, and symptomatic epilepsy (PMSE). In another common pathology associated with IS, focal cortical dysplasias type IIB (FCDIIB) with balloon cells, loss of heterozygocity, and polymorphisms of the tuberous sclerosis complex 1 (TSC1) gene (inhibitor of mTOR activity) or overactivation of downstream targets on mTOR (e.g., phosphorylated ribosomal S6 protein [pS6]) have been described.

We used the multiple-hit model of IS, a nongenetic model of acquired brain injury, to test whether mTOR overactivation could be implicated in epileptic spasms of acquired structural etiology. Indeed, overactivation of downstream targets of the mTOR was seen during the period of spasms at the peri-infusional area. Most importantly, a pulse 3-d high-dose treatment with the mTOR inhibitor rapamycin, initiated after the onset of spasms, stopped spasms and partially improved learning, suggesting disease modification (Raffo et al. 2011).

Given the clinical evidence that early cessation of spasms may improve neurodevelopmental outcomes (Lombroso 1983; Kivity et al. 
2004; Lux et al. 2005; Darke et al. 2010), at least in infants with IS of unknown etiology, we were interested in therapies that achieve rapid onset reduction of spasms when given after their onset. Among these drugs, a single injection of carisbamate, an investigational drug with a broad range of preclinical efficacy in various animal models of seizures, showed immediate reduction of spasms during the first $3 \mathrm{~h}$ of monitoring (Ono et al. 2011). This effect was not attributed to sodium channel blockade, and its mechanism is yet unknown. Carisbamate has currently been given orphan drug indication for IS by the Federal Drug Administration (FDA).

\section{Lessons from Animal Models of IS}

In summary, modeling IS in rodents has presented challenges and opportunities to advance our understanding of the pathogenesis and treatment of IS. The species-related differences in biology and neurodevelopmental stages, and the rapid evolution of changes occurring during development present challenges in across-species extrapolation of mechanisms and treatment evaluation (Galanopoulou and Moshé 2011). This is likely to present a considerable challenge in across-model validation of future candidate treatments for IS, and may require careful reassessment of the strategies for treatment identification and validation for this condition, which is in dire need of better therapies. Furthermore, technical limitations in placing enough electrodes on the head of very young rats to document hypsarrhythmia restrict our ability to document and study hypsarrhythmia at ages that are considered equivalent to the infantile stage in humans.

Regardless, there are several mechanisms that emerge as candidate potentially pathogenic pathways. Interneuronopathies, whether of genetic (ARX models and clinical reports) or acquired (multiple-hit) origin, has been implicated in the expression of IS and subsequent epilepsy or behavioral and cognitive comorbidities. Dysregulation of the mTOR pathway has been associated with both genetic (e.g., tuberous sclerosis), somatic (FCDIIB), and acquired etiologies (multiple-hit model) of IS and subsequent cognitive or epilepsy chronic phenotype. NMDA-dependent pathways have been implicated in the expression of acute tonic flexion spasms, although there is not yet evidence that the chronic disease phenotype of IS ensues. Perinatal stress seems to increase the severity of spasms in NMDA-exposed animals through an ACTH-dependent manner, but cannot recapitulate the chronic phenotype of IS. Finally, $\mathrm{GABA}_{\mathrm{B}}$ receptor activation has been implicated in the expression of spasms in Down syndrome, although no evidence yet that these suffice to reproduce the chronicity of the syndrome.

\section{Animal Models of Dravet Syndrome}

Dravet syndrome usually manifests $\sim 6$ mo of age with prolonged febrile seizures, clonic or hemiclonic. The afebrile epileptic seizures that also occur in this syndrome include myoclonic, atypical absences, focal onset, or generalized seizures, which are usually not responsive to available antiseizure drugs. Dravet syndrome is also associated with a high incidence of sudden death in epilepsy (SUDEP). Although other genes have been described as well (e.g., SCN1B), $70 \%-80 \%$ of infants with Dravet syndrome have mutations of the SCN1A gene (or $\mathrm{Na}_{\mathrm{v}} 1.1$ ). The SCN1A gene is also affected in a different syndrome, $\mathrm{GEFS}^{+}$(genetic epilepsy with febrile seizure plus syndrome), which has a less malignant course and is characterized by increased incidence of febrile and afebrile seizures, focal or generalized in the same families. It has been proposed that a differentiating factor between the different genotype-phenotype profiles of the two syndromes is the functional impact of the SCN1A mutations. Loss-of-function mutations have been associated with Dravet syndrome and missense mutations altering channel activity have been linked to $\mathrm{GEFS}^{+}$(Escayg and Goldin 2010).

Several mouse strains have been generated with either deletion or KI mutations of the SCN1A gene (Table 5), reproducing various syndromic features (seizures, thermal sensitivity, premature death) of Dravet syndrome or $\mathrm{GEFS}^{+}$. Whereas homozygous mice have a se- 
A.S. Galanopoulou and S.L. Moshé
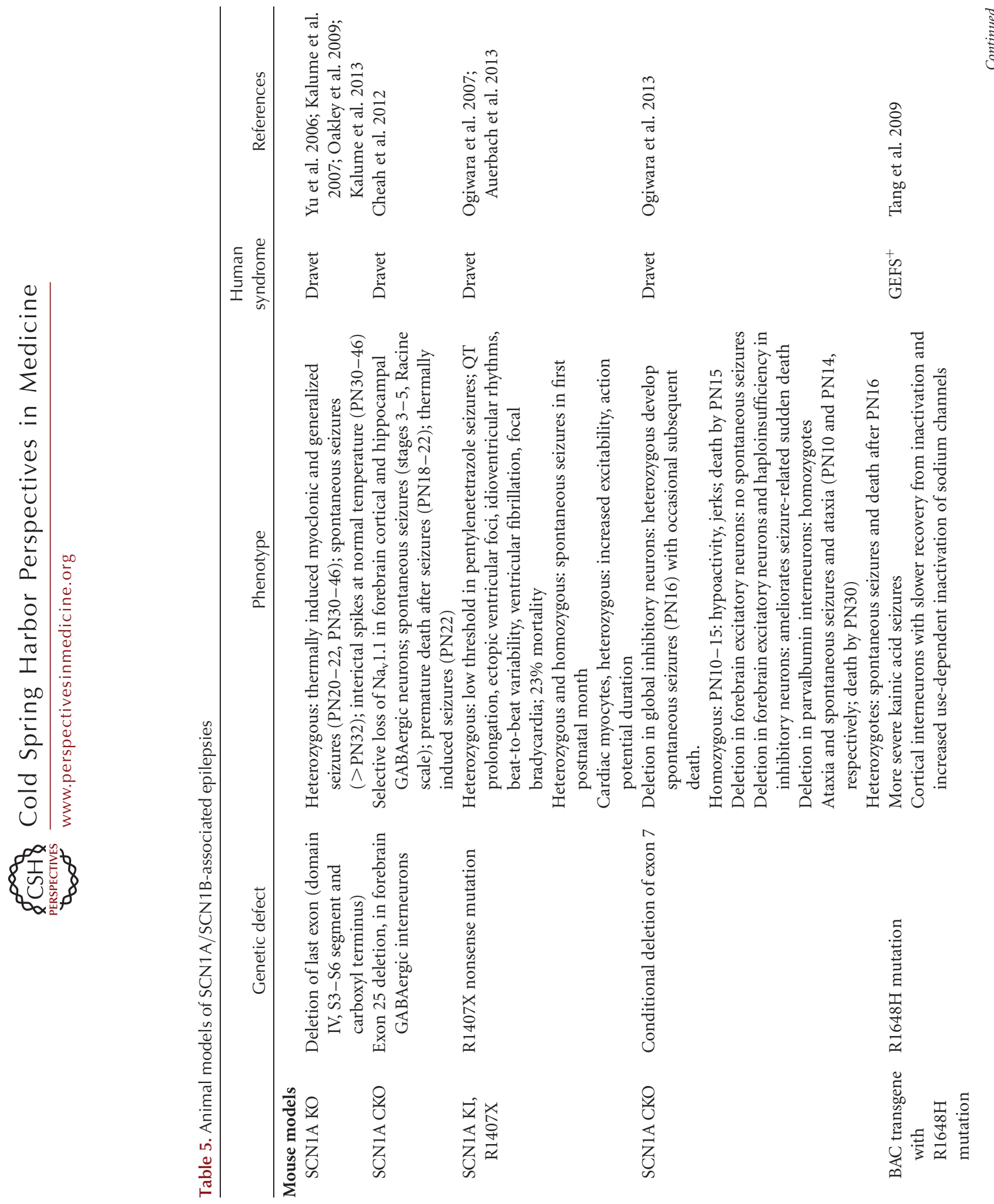
Animal Models of Early-Life Epilepsy
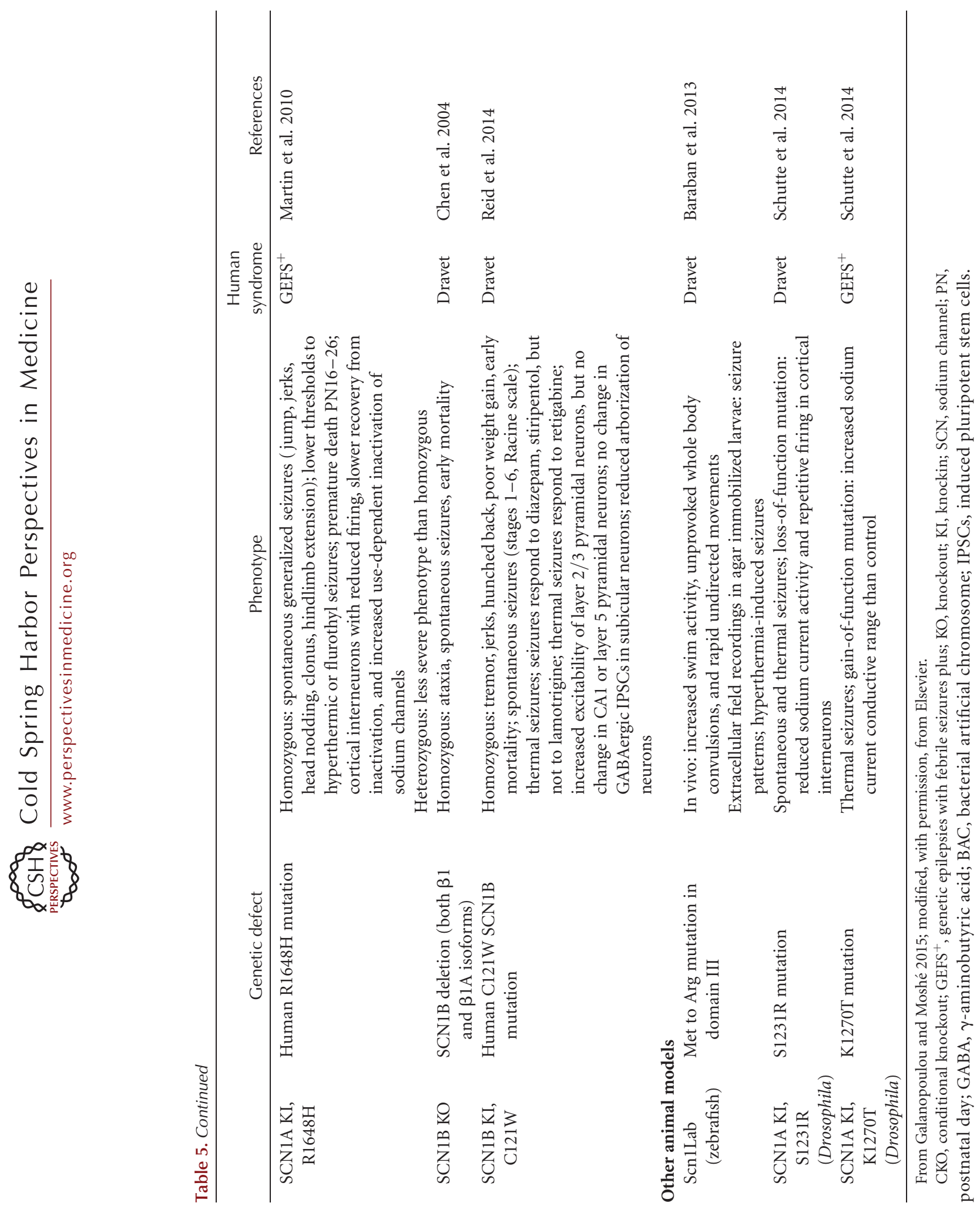
vere phenotype with spontaneous seizures, thermally induced seizures, and early death, often in the hours following a generalized seizure, the severity of the phenotype of heterozygous mice with SCN1A deletion may vary according to the genetic background (Mullen and Scheffer 2009).

The use of CKO mice revealed interesting aspects of the cellular and molecular physiology of the disease. Selective SCN1A deletion in inhibitory interneurons is sufficient to generate epilepsy, thermally induced seizures, and premature death after seizures (Cheah et al. 2012; Ogiwara et al. 2013). Furthermore, ataxia and epilepsy can be induced by selective deletion of the gene within parvalbumin-positive interneurons (Ogiwara et al. 2013). In contrast, SCN1A deletion within excitatory neurons of the forebrain does not produce epilepsy (Ogiwara et al. 2013). This is further supported by the observation that focal deletion of SCN1A in basal forebrain neurons does not result in epilepsy, but causes dysregulation of hippocampal oscillations and spatial memory deficit (Bender et al. 2013). Even more interestingly, combined deletion in both inhibitory and forebrain excitatory neurons ameliorates the seizure-related sudden death expected from the interneuronal CKO (Ogiwara et al. 2013). Consequently, these studies again suggest the key role of interneurons in the pathogenesis of Dravet syndrome, posing that loss of function of SCN1A may impair the function of inhibitory interneurons and augment the excitatory effects of excitatory neurons, leading to severe seizures and, in certain cases, death.

A few studies investigated the underlying causes of sudden death in this syndrome. Studies in the deletion mutants indicate that death follows generalized seizures, consistent with the idea that this may represent SUDEP. Further incriminating a central, possibly seizure-related, etiology, CKO with brain- versus cardiac-specific knockouts (KOs) of the gene indicate that early mortality is primarily an aspect of the brain-specific KO (Kalume et al. 2013). In contrast, using a KI mouse, whereby the human SCN1A-R1407X mutation is inserted in the mouse genome, prominent cardiac abnormali- ties were found in the form of long QT, ectopic ventricular foci, idioventricular rhythms, beatto-beat variability, ventricular fibrillation, and focal bradycardia (Auerbach et al. 2013). Cardiac myocytes from heterozygous mice also showed increased excitability and action potential duration (Auerbach et al. 2013). Aview that reconciles these findings is that, probably, both central and cardiac pathologies underlie early mortality in Dravet syndrome and the seizurerelated repetitive stress on the cardiac function may render it difficult to compensate for the already abnormal physiology of the cardiac myocyte in Dravet syndrome, leading to high probability for early death during the periods following a generalized seizure.

Different studies evaluating the electrophysiological properties of cortical inhibitory interneurons bearing mutations of the SCN1A that are associated with $\mathrm{GEFS}^{+}$show that they have reduced firing, slower recovery from inactivation, and increased use-dependent inactivation of sodium channels (Tang et al. 2009; Martin et al. 2010).

In addition to the mouse models, a zebrafish model of Dravet syndrome was recently reported as a high-throughput model for the screen of new therapeutics (Table 5) (Baraban et al. 2013). Identification of seizures is based on the type and frequency of swim activity, whereas electrographic recordings are performed in agar-embedded and immobilized larvae. Drug screening in this model suggested antiseizure effects for ketogenic diet, diazepam, valproate, potassium bromide, and stiripentol, whereas other antiepileptics, such as vigabatrin, carbamazepine, ethosuximide, and phenytoin, had no effect. Furthermore, a role for clemizole (H1 antagonist, NS4B RNA-inhibitor) as an antiseizure drug was proposed, although further validation awaits in other models.

KI Drosophila mutants for two SCN1A mutations found in Dravet (S1231R) or GEFS ${ }^{+}$ (K1270T) syndromes produced evidence for differences in genotype-phenotype, which was more severe in the Dravet mutation (Table 5), but also produced different possible underlying mechanisms for thermally induced seizures because the Dravet mutation resulted in loss of 
function and the GEFS ${ }^{+}$in gain of function (Schutte et al. 2014).

The SCN1B mouse models, however, reveal certain peculiarities in the underlying molecular and cellular mechanisms of these syndromes. The SCN1B KO mouse model did not reveal any changes in the sodium current activity in cultured dissociated hippocampal neurons, which is thought to be caused by antiparallel decrease in $\mathrm{Na}_{\mathrm{v}} 1.1$ and increase in $\mathrm{Na}_{\mathrm{v}} 1.3$ expression (Chen et al. 2004). In contrast, a mouse KI model of SCN1B human mutation found in Dravet syndrome (C121W) supports the fact that increased excitability of excitatory neurons is directly implicated in this condition with no observed changes in $\mathrm{GABA}_{\mathrm{A}}$ receptor transmission (Reid et al. 2014).

In summary, the animal models of sodium channelopathies (Dravet or $\mathrm{GEFS}^{+}$) have provided evidence of a functional interneuronopathy as being key for the pathogenesis of the thermally induced and spontaneous seizures in SCN1A, but not SCN1B genetic defects. Compensatory increase in other sodium channel subunits (e.g., of $\mathrm{Na}_{\mathrm{v}} 1.3$ in $\mathrm{SCN} 1 \mathrm{~B}$ deletion mouse) or downstream changes in neurons receiving input from the genetically affected neurons (e.g., amelioration of phenotype by dual deletion of SCN1A in both interneurons and forebrain excitatory neurons) may modify the severity of the phenotype and possibly the age specificity of the syndrome.

\section{ANIMAL MODELS OF EARLY-LIFE EPILEPSIES AND MALFORMATIONS}

\section{Models of mTOR Dysregulation}

Dysregulation of mTOR is implicated in a number of early-life epilepsies, with the main representative being TSC (Chu-Shore et al. 2010). TSC is usually caused by mutations in either of the two regulators of the mammalian target of rapamycin complex 1 (mTORC1) activity, TSC1, or TSC2 (Galanopoulou et al. 2012b; Crino 2013; Wong 2013). IS manifests in $\sim 38 \%$ of individuals with TSC mutations (Chu-Shore et al. 2010). There are several mouse models with constitutive or conditional
TSC1 or TSC2 mutations (Table 1) (Uhlmann et al. 2002; Meikle et al. 2007; Wang et al. 2007; Ehninger et al. 2008; Zeng et al. 2011; Fu et al. 2012). Among these, spontaneous seizures appear in the neuronal $\mathrm{Tsc}^{-/+}\left(\mathrm{Tscl}^{\text {null-neuron }}\right)$, glial $\mathrm{CKOs}\left(\mathrm{Tsc}^{\mathrm{GFAP}} \mathrm{CKO}, \mathrm{Tsc}^{\mathrm{GFAP1}} \mathrm{CKO}\right)$. Tsc2 ${ }^{\mathrm{GFAP1}} \mathrm{CKO}$ mice have more severe epilepsy phenotype than the $\mathrm{Tsc}^{\mathrm{GFAP}} \mathrm{CKO}$, with seizures appearing within the first month of life, before the early mortality that ensues. Interneuronal KO of TSC1 gene ( Tscl $\left.{ }^{\text {interneuronal }} \mathrm{CKO}\right)$ does not manifest epilepsy, although a reduced number of GABAergic interneurons and lower flurothyl seizure thresholds are reported. Most of the TSC mouse models manifest with abnormal morphology of neurons and cognitive deficits. Furthermore, these models have offered a unique opportunity to test the value of genetargeted therapies (mTOR inhibitors, such as rapamycin) in the treatment of the associated epilepsies and neurodevelopmental and pathology findings (Ehninger et al. 2008; Zeng et al. 2008).

Phosphatase and tensin homolog deleted on chromosome ten (PTEN) is a lipid phosphatase that indirectly controls mTOR activity by inhibiting the phosphatidylinositol-3 kinase (PI3K). Mutations of this gene have been identified in conditions associated with brain malformations or dysplasias, some of which have been linked with epilepsies or autism (Galanopoulou et al. 2012b). Mouse models with KO of PTEN from neurons (NS-PTEN) manifest cognitive and behavioral deficits, as well as seizures that are improved by rapamycin (Ljungberg et al. 2009; Zhou et al. 2009; Sunnen et al. 2011). A forebrain-specific deletion of PTEN from excitatory neurons (NEX-PTEN) results in early lethality and enlargement of the forebrain, although no seizures were reported (Kazdoba et al. 2012). In contrast, selective deletion of PTEN in dentate granule neurons results in epilepsy within a month (Pun et al. 2012).

\section{Other Models of Focal Malformations}

Other attempts to generate epilepsies associated with malformation have been performed using methylazoxymethanol acetate (MAM) or focal 
cooling have succeeded in generating the dysplasias, although a second hit is necessary to trigger seizures (Scantlebury et al. 2005; Pun et al. 2012). However, spontaneous seizures have been reported in the in utero irradiation model (mild or moderate, but not with severe) (Kellinghaus et al. 2004), as well as in the Tish rat (telencephalic internal structural heterotopia) (Trotter et al. 2006), although seizures manifest at older ages.

\section{ANIMAL MODELS OF OTHER EARLY-LIFE EPILEPSIES OF GENETIC ORIGIN}

A more exhaustive review of epilepsy genes and related animal models can be found in Vezzani et al. (2015). Here, we refer to selected genetic animal models that manifest or were constructed based on genes associated with early-life epilepsies.

Early epileptic encephalopathy with suppression burst or Ohtahara syndrome has been linked with syntaxin binding protein 1 (STXBP1) gene mutations. A mouse model of STXBP1 generated in C57BL/6J background shows increased anxiety, but no seizures. However, the investigators report that this may be a result of the genetic background, as mixed C57BL/6J $\times 129 S 1 / S V$ background permitted the expression of spontaneous seizures (Hager et al. 2014).

Benign familial neonatal convulsions are attributed to KCNQ2 or KCNQ3 (potassium channels) mutations and are autosomal dominant disorders whereby newborns manifest frequent daily focal or generalized seizures, which spontaneously remit by 3-4 mo of age. KCNQ2 and KCNQ3 generate the M-current, which regulates the action potential firing. Among the attempts to generate a KCNQ2 mouse model of epilepsy are the KI mice bearing the A306T KCNQ2 or the G311V KCNQ3 loss-of-function mutations (Singh et al. 2008). Heterozygous mice have reduced seizure thresholds in a variety of seizure models, whereas homozygous mice show epilepsy into adulthood (Singh et al. 2008; Otto et al. 2009).

Pyridoxine dependency manifests as earlylife seizures that may be treated with high doses of vitamin B6 or pyridoxal 5'phosphate (PLP). A genetic mutation of tissue-nonspecific alkaline phosphatase (TNAP) in mice results in seizures that are caused by defective metabolism of PLP, which results in reduced production of GABA, as this factor is needed for the activity of its synthesizing enzyme, glutamate decarboxylase (GAD) (Waymire et al. 1995).

\section{CONCLUDING REMARKS}

The increasing understanding of the dynamic changes and distinct neurobiology of the developing brain has prompted the realization that observations made in models of epilepsies created in mature (adult) animals cannot be extrapolated for neonatal or infantile onset epilepsies. Significant advances, over the last 50 years, have been performed in generating animal models of early-life epilepsies and specific neonatal and infantile epileptic syndromes. Such studies have reconfirmed the pathogenic role of certain genes and acquired insults for such epilepsies and associated comorbidities. We are now in the stage that therapy development, for the first time, may start directly in these immature animal models rather than repurposing or expanding the use of drugs validated in adult models. However, there are challenges, including the extensive list of genetic, environmental, and epigenetic factors that define the phenotype and outcomes; the difficulties extrapolating developmental ages across species or validating hypotheses or treatments across models developed in different ages, species, or strains; the need for specialized batteries of tests that can fully capture the complexities of comorbidities, seizures, and side effects observed in humans; and the obstacles in translating preclinical discoveries to clinically relevant therapies (Galanopoulou and Moshé 2011; Galanopoulou et al. 2012a). Despite these, there are a number of mechanistic theories that emerge as strong contributors in the pathogenesis of early-life epileptic syndromes, such as interneuronopathies (IS, Dravet syndrome), mTOR dysregulation (brain malformations, tuberous sclerosis, IS of acquired structural lesions). In addition, new drugs have emerged, 
acquiring orphan drug status for IS (CPP-115, carisbamate [Catalyst Pharmaceutical Partners, Coral Gables, FL], carisbamate [SK Biopharmaceuticals]), based on work performed in immature animal models or are being developed with the intent to specifically target mechanisms identified in these models (neonatal estradiol for ARX-related IS), raising hopes and promise for the future.

\section{ACKNOWLEDGMENTS}

A.S.G. receives research funding from The $\mathrm{Na}-$ tional Institute of Neurological Disorders and Stroke (NINDS) NS078333, U.S. Department of Defense (W81XWH-13-1-0180) CURE, UCB, the Heffer Family and the Segal Family Foundations, and the Abbe Goldstein/Joshua Lurie and Laurie Marsh/Dan Levitz families. She has received royalties for book publishing from Morgan and Claypool Publishers, honoraria from the Department of Defense (grant reviews), John Libbey Eurotext, and Elsevier (publications). S.L.M. is the Charles Frost Chair in Neurosurgery and Neurology and is funded by grants from National Institutes of Health (NIH) NS43209, NS20253, NS45911, NS78333, CURE, U.S. Department of Defense (W81XWH-13-1-0180), UCB, the Heffer Family and the Segal Family Foundations, and the Abbe Goldstein/Joshua Lurie and Laurie Marsh/Dan Levitz families. He receives from Elsevier an annual compensation for his work as Associate Editor in Neurobiology of Disease and royalties from two books that he coedited. He received a consultant fee from Lundbeck and UCB. There are no conflicts of interest related to this manuscript.

\section{REFERENCES}

${ }^{*}$ Reference is also in this collection.

Akman O, Briggs SW, Galanopoulou AS. 2012. Long-term follow up of the multiple-hit model of symptomatic infantile spasms. Epilepsy Curr 13: 147.

Akman O, Moshé SL, Galanopoulou AS. 2014. Sex-specific consequences of early life seizures. Neurobiol Dis 72: 153-166.

Auerbach DS, Jones J, Clawson BC, Offord J, Lenk GM, Ogiwara I, Yamakawa K, Meisler MH, Parent JM, Isom
LL. 2013. Altered cardiac electrophysiology and SUDEP in a model of Dravet syndrome. PloS ONE 8: e77843.

Auvin S, Hartman AL, Desnous B, Moreau AC, Alberti C, Delanoe C, Romano A, Terrone G, Kossoff EH, Del Giudice E, et al. 2012. Diagnosis delay in West syndrome: Misdiagnosis and consequences. Eur J Pediatr 171: 1695-1701.

Avishai-Eliner S, Brunson KL, Sandman CA, Baram TZ. 2002. Stressed-out, or in (utero)? Trends Neurosci 25: 518-524.

Baraban SC, Dinday MT, Hortopan GA. 2013. Drug screening in Scnla zebrafish mutant identifies clemizole as a potential Dravet syndrome treatment. Nat Commun 4: 2410.

Baram TZ. 1993. Pathophysiology of massive infantile spasms: Perspective on the putative role of the brain adrenal axis. Ann Neurol 33: 231-236.

Baram TZ, Schultz L. 1995. ACTH does not control neonatal seizures induced by administration of exogenous corticotropin-releasing hormone. Epilepsia 36: 174-178.

Baram TZ, Mitchell WG, Snead OC III, Horton EJ, Saito M. 1992. Brain-adrenal axis hormones are altered in the CSF of infants with massive infantile spasms. Neurology 42: $1171-1175$.

Baram TZ, Mitchell WG, Tournay A, Snead OC, Hanson RA, Horton EJ. 1996. High-dose corticotropin (ACTH) versus prednisone for infantile spasms: A prospective, randomized, blinded study. Pediatrics 97: 375-379.

Baumbach HD, Chow KL. 1981. Visuocortical epileptiform discharges in rabbits: Differential effects on neuronal development in the lateral geniculate nucleus and superior colliculus. Brain Res 209: 61-76.

Beguin S, Crepel V, Aniksztejn L, Becq H, Pelosi B, PallesiPocachard E, Bouamrane L, Pasqualetti M, Kitamura K, Cardoso C, et al. 2013. An epilepsy-related ARX polyalanine expansion modifies glutamatergic neurons excitability and morphology without affecting GABAergic neurons development. Cereb Cortex 23: 1484-1494.

Bender AC, Natola H, Ndong C, Holmes GL, Scott RC, Lenck-Santini PP. 2013. Focal Scnla knockdown induces cognitive impairment without seizures. Neurobiol Dis 54: 297-307.

Berg AT, Berkovic SF, Brodie MJ, Buchhalter J, Cross JH, van Emde Boas W, Engel J, French J, Glauser TA, Mathern GW, et al. 2010. Revised terminology and concepts for organization of seizures and epilepsies: Report of the ILAE Commission on Classification and Terminology, 2005-2009. Epilepsia 51: 676-685.

Bombardieri R, Pinci M, Moavero R, Cerminara C, Curatolo P. 2010. Early control of seizures improves long-term outcome in children with tuberous sclerosis complex. Eur J Paediatr Neurol 14: 146-149.

Briggs SW, Mowrey W, Hall CB, Galanopoulou AS. 2014. CPP-115, a vigabatrin analogue, decreases spasms in the multiple-hit rat model of infantile spasms. Epilepsia 55: 94-102.

Capovilla G, Wolf P, Beccaria F, Avanzini G. 2013. The history of the concept of epileptic encephalopathy. Epilepsia 54: $2-5$. 
Chachua T, Yum MS, Veliskova J, Velisek L. 2011. Validation of the rat model of cryptogenic infantile spasms. Epilepsia 52: 1666-1677.

Cheah CS, Yu FH, Westenbroek RE, Kalume FK, Oakley JC, Potter GB, Rubenstein JL, Catterall WA. 2012. Specific deletion of $\mathrm{Na}_{\mathrm{V}} 1.1$ sodium channels in inhibitory interneurons causes seizures and premature death in a mouse model of Dravet syndrome. Proc Natl Acad Sci 109: 14646-14651.

Chen C, Westenbroek RE, Xu X, Edwards CA, Sorenson DR, Chen Y, McEwen DP, O'Malley HA, Bharucha V, Meadows LS, et al. 2004. Mice lacking sodium channel $\beta 1$ subunits display defects in neuronal excitability, sodium channel expression, and nodal architecture. J Neurosci 24: 4030-4042.

Chow KL, Baumbach HD, Glanzman DL. 1978. Abnorma development of lateral geniculate neurons in rabbit subjected to either eyelid closure or corticofugal paroxysmal discharges. Brain Res 146: 151-158.

Chu-Shore CJ, Major P, Camposano S, Muzykewicz D Thiele EA. 2010. The natural history of epilepsy in tuberous sclerosis complex. Epilepsia 51: 1236-1241.

Cohen-Sadan S, Kramer U, Ben-Zeev B, Lahat E, Sahar E, Nevo Y, Eidlitz T, Zeharia A, Kivity S, Goldberg-Stern H. 2009. Multicenter long-term follow-up of children with idiopathic West syndrome: ACTH versus vigabatrin. Eur J Neurol 16: 482-487.

Coleman M. 1971. Infantile spasms associated with 5-hydroxytryptophan administration in patients with Down's syndrome. Neurology 21: 911-919.

Cortez MA, Shen L, Wu Y, Aleem IS, Trepanier CH, Sadeghnia HR, Ashraf A, Kanawaty A, Liu CC, Stewart L, et al. 2009. Infantile spasms and Down syndrome: A new animal model. Pediatr Res 65: 499-503.

Crino PB. 2013. Evolving neurobiology of tuberous sclerosis complex. Acta Neuropathol 125: 317-332.

Curatolo P, Seri S, Verdecchia M, Bombardieri R. 2001. Infantile spasms in tuberous sclerosis complex. Brain Dev 23: $502-507$.

Darke K, Edwards SW, Hancock E, Johnson AL, Kennedy CR, Lux AL, Newton RW, O'Callaghan FJ, Verity CM, Osborne JP, et al. 2010. Developmental and epilepsy outcomes at age 4 years in the UKISS trial comparing hormonal treatments to vigabatrin for infantile spasms: A multi-centre randomised trial. Arch Dis Child 95: $382-$ 386.

Dobbing J, Sands J. 1979. Comparative aspects of the brain growth spurt. Early Hum Dev 3: 79-83.

Dobyns WB, Berry-Kravis E, Havernick NJ, Holden KR, Viskochil D. 1999. X-linked lissencephaly with absent corpus callosum and ambiguous genitalia. Am J Med Genet 86: 331-337.

Ehlers CL, Henriksen SJ, Wang M, Rivier J, Vale W, Bloom FE. 1983. Corticotropin releasing factor produces increases in brain excitability and convulsive seizures in rats. Brain Res 278: 332-336.

Ehninger D, Han S, Shilyansky C, Zhou Y, Li W, Kwiatkowski DJ, Ramesh V, Silva AJ. 2008. Reversal of learning deficits in a $\mathrm{Tsc}^{+/-}$mouse model of tuberous sclerosis. Nat Med 14: $843-848$.
Epi4K Consortium; Epilepsy Phenome/Genome Project; Allen AS, Berkovic SF, Cossette P, Delanty N, Dlugos D, Eichler EE, Epstein MP, Glauser T, et al. 2013. De novo mutations in epileptic encephalopathies. Nature 501: 217-221.

Escayg A, Goldin AL. 2010. Sodium channel SCN1A and epilepsy: Mutations and mechanisms. Epilepsia 51: 1650-1658.

Friocourt G, Parnavelas JG. 2010. Mutations in ARX result in several defects involving GABAergic neurons. Front Cell Neurosci 4: 4.

Frost JD Jr, Hrachovy RA. 2005. Pathogenesis of infantile spasms: A model based on developmental desynchronization. J Clin Neurophysiol 22: 25-36.

Frost JD Jr, Lee CL, Hrachovy RA, Swann JW. 2011. High frequency EEG activity associated with ictal events in an animal model of infantile spasms. Epilepsia 52: 53-62.

Frost JD Jr, Lee CL, Le JT, Hrachovy RA, Swann JW. 2012. Interictal high frequency oscillations in an animal model of infantile spasms. Neurobiol Dis 46: 377-388.

Fu C, Cawthon B, Clinkscales W, Bruce A, Winzenburger P, Ess KC. 2012. GABAergic interneuron development and function is modulated by the Tsc1 gene. Cereb Cortex 22: 2111-2119.

Galanopoulou AS. 2013. Basic mechanisms of catastrophic epilepsy-Overview from animal models. Brain Dev 35: 748-756.

Galanopoulou AS, Moshé SL. 2011. In search of epilepsy biomarkers in the immature brain: Goals, challenges and strategies. Biomark Med 5: 615-628.

Galanopoulou AS, Moshé SL. 2015. Pathogenesis and new candidate treatments for infantile spasms and early life epileptic encephalopathies: A view from preclinical studies. Neurobiol Dis 79: 135-149.

Galanopoulou AS, Buckmaster PS, Staley KJ, Moshe SL, Perucca E, Engel J Jr, Loscher W, Noebels JL, Pitkanen A, Stables J, et al. 2012a. Identification of new epilepsy treatments: Issues in preclinical methodology. Epilepsia 53: $571-582$.

Galanopoulou AS, Gorter JA, Cepeda C. 2012b. Finding a better drug for epilepsy: The mTOR pathway as an antiepileptogenic target. Epilepsia 53: 1119-1130.

Go CY, Mackay MT, Weiss SK, Stephens D, Adams-Webber T, Ashwal S, Snead OC III, Child Neurology Society, American Academy of Neurology. 2012. Evidence-based guideline update: Medical treatment of infantile spasms. Report of the Guideline Development Subcommittee of the American Academy of Neurology and the Practice Committee of the Child Neurology Society. Neurology 78: $1974-1980$.

Goldberg-Stern H, Strawsburg RH, Patterson B, Hickey F, Bare M, Gadoth N, Degrauw TJ. 2001. Seizure frequency and characteristics in children with Down syndrome. Brain Dev 23: 375-378.

Gottlieb A, Keydar I, Epstein HT. 1977. Rodent brain growth stages: An analytical review. Biol Neonate 32: 166-176.

Hager T, Maroteaux G, Pont P, Julsing J, van Vliet R, Stiedl O. 2014. Munc18-1 haploinsufficiency results in enhanced anxiety-like behavior as determined by heart rate responses in mice. Behav Brain Res 260: 44-52. 
Hauser WA, Annegers JF, Kurland LT. 1993. Incidence of epilepsy and unprovoked seizures in Rochester, Minnesota: 1935-1984. Epilepsia 34: 453-468.

Holmes GL, Lenck-Santini PP. 2006. Role of interictal epileptiform abnormalities in cognitive impairment. Epilepsy Behav 8: 504-515.

Insel TR, Battaglia G, Fairbanks DW, De Souza EB. 1988. The ontogeny of brain receptors for corticotropin-releasing factor and the development of their functional association with adenylate cyclase. J Neurosci 8: 4151-4158.

Jequier Gygax M, Klein BD, White HS, Kim M, Galanopoulou AS. 2014. Efficacy and tolerability of the galanin analog NAX 5055 in the multiple-hit rat model of symptomatic infantile spasms. Epilepsy Res 108: 98-108.

Kabova R, Liptakova S, Slamberova R, Pometlova M, Velisek L. 1999. Age-specific $N$-methyl-D-aspartate-induced seizures: Perspectives for the West syndrome model. Epilepsia 40: 1357-1369.

Kalume F, Yu FH, Westenbroek RE, Scheuer T, Catterall WA 2007. Reduced sodium current in Purkinje neurons from $\mathrm{Na}_{\mathrm{v}} 1.1$ mutant mice: Implications for ataxia in severe myoclonic epilepsy in infancy. J Neurosci 27: $11065-$ 11074.

Kalume F, Westenbroek RE, Cheah CS, Yu FH, Oakley JC, Scheuer T, Catterall WA. 2013. Sudden unexpected death in a mouse model of Dravet syndrome. J Clin Invest 123: $1798-1808$.

Karvelas G, Lortie A, Scantlebury MH, Duy PT, Cossette P, Carmant L. 2009. A retrospective study on aetiology based outcome of infantile spasms. Seizure 18: 197-201.

Kato M. 2006. A new paradigm for West syndrome based on molecular and cell biology. Epilepsy Res 70: S87-S95.

Kato M, Dobyns WB. 2005. X-linked lissencephaly with abnormal genitalia as a tangential migration disorder causing intractable epilepsy: Proposal for a new term, "interneuronopathy." J Child Neurol 20: 392-397.

Kato M, Das S, Petras K, Sawaishi Y, Dobyns WB. 2003. Polyalanine expansion of ARX associated with cryptogenic West syndrome. Neurology 61: 267-276.

Kato M, Saitoh S, Kamei A, Shiraishi H, Ueda Y, Akasaka M, Tohyama J, Akasaka N, Hayasaka K. 2007. A longer polyalanine expansion mutation in the ARX gene causes early infantile epileptic encephalopathy with suppressionburst pattern (Ohtahara syndrome). Am J Hum Genet 81: $361-366$.

Kazdoba TM, Sunnen CN, Crowell B, Lee GH, Anderson AE, D'Arcangelo G. 2012. Development and characterization of NEX-Pten, a novel forebrain excitatory neuronspecific knockout mouse. Dev Neurosci 34: 198-209.

Kellinghaus C, Kunieda T, Ying Z, Pan A, Luders HO, Najm IM. 2004. Severity of histopathologic abnormalities and in vivo epileptogenicity in the in utero radiation model of rats is dose dependent. Epilepsia 45: 583-591.

Khan OI, Zhao Q, Miller F, Holmes GL. 2010. Interictal spikes in developing rats cause long-standing cognitive deficits. Neurobiol Dis 39: 362-371.

Kitamura K, Yanazawa M, Sugiyama N, Miura H, IizukaKogo A, Kusaka M, Omichi K, Suzuki R, Kato-Fukui Y, Kamiirisa K, et al. 2002. Mutation of ARX causes abnormal development of forebrain and testes in mice and
$\mathrm{X}$-linked lissencephaly with abnormal genitalia in humans. Nat Genet 32: 359-369.

Kitamura K, Itou Y, Yanazawa M, Ohsawa M, SuzukiMigishima R, Umeki Y, Hohjoh H, Yanagawa Y, Shinba T, Itoh M, et al. 2009. Three human ARX mutations cause the lissencephaly-like and mental retardation with epilepsy-like pleiotropic phenotypes in mice. Hum Mol Genet 18: 3708-3724.

Kivity S, Lerman P, Ariel R, Danziger Y, Mimouni M, Shinnar S. 2004. Long-term cognitive outcomes of a cohort of children with cryptogenic infantile spasms treated with high-dose adrenocorticotropic hormone. Epilepsia 45: 255-262.

Kubova H, Mares P. 2010. Vigabatrin but not valproate prevents development of age-specific flexion seizures induced by $N$-methyl-D-aspartate (NMDA) in immature rats. Epilepsia 51: 469-472.

Lado FA, Moshé SL. 2002. Role of subcortical structures in the pathogenesis of infantile spasms: What are possible subcortical mediators? Int Rev Neurobiol 49: 115-140.

Lee CL, Frost JD Jr, Swann JW, Hrachovy RA. 2008. A new animal model of infantile spasms with unprovoked persistent seizures. Epilepsia 49: 298-307.

Lee J, Lee JH, Yu HJ, Lee M. 2013. Prognostic factors of infantile spasms: Role of treatment options including a ketogenic diet. Brain Dev 35: 821-826.

Ljungberg MC, Sunnen CN, Lugo JN, Anderson AE, D'Arcangelo G. 2009. Rapamycin suppresses seizures and neuronal hypertrophy in a mouse model of cortical dysplasia. Disease Model Mech 2: 389-398.

Lombroso CT. 1983. A prospective study of infantile spasms: Clinical and therapeutic correlations. Epilepsia 24: 135158.

Lux AL, Osborne JP. 2006. The influence of etiology upon ictal semiology, treatment decisions and long-term outcomes in infantile spasms and West syndrome. Epilepsy Res 70: S77-S86.

Lux AL, Edwards SW, Hancock E, Johnson AL, Kennedy CR, Newton RW, O'Callaghan FJ, Verity CM, Osborne JP; United Kingdom Infantile Spasms Study. 2005. The United Kingdom Infantile Spasms Study (UKISS) comparing hormone treatment with vigabatrin on developmental and epilepsy outcomes to age 14 months: A multicentre randomised trial. Lancet Neurol 4: 712-717.

Mackay MT, Weiss SK, Adams-Webber T, Ashwal S, Stephens D, Ballaban-Gill K, Baram TZ, Duchowny M, Hirtz D, Pellock JM, et al. 2004. Practice parameter: Medical treatment of infantile spasms: Report of the American Academy of Neurology and the Child Neurology Society. Neurology 62: 1668-1681.

Mares P, Velisek L. 1992. N-methyl-D-aspartate (NMDA)induced seizures in developing rats. Brain Res Dev Brain Res 65: 185-189.

Marsh E, Fulp C, Gomez E, Nasrallah I, Minarcik J, Sudi J, Christian SL, Mancini G, Labosky P, Dobyns W, et al. 2009. Targeted loss of Arx results in a developmental epilepsy mouse model and recapitulates the human phenotype in heterozygous females. Brain 132: 1563-1576.

Martin MS, Dutt K, Papale LA, Dube CM, Dutton SB, de Haan G, Shankar A, Tufik S, Meisler MH, Baram TZ, et al. 2010. Altered function of the SCN1A voltagegated sodium channel leads to $\gamma$-aminobutyric acid-ergic 
(GABAergic) interneuron abnormalities. J Biol Chem 285: 9823-9834.

McCarthy MM. 2008. Estradiol and the developing brain. Physiol Rev 88: 91-124.

Meikle L, Talos DM, Onda H, Pollizzi K, Rotenberg A, Sahin M, Jensen FE, Kwiatkowski DJ. 2007. A mouse model of tuberous sclerosis: Neuronal loss of Tscl causes dysplastic and ectopic neurons, reduced myelination, seizure activity, and limited survival. J Neurosci 27: 5546-5558.

Mohamed BP, Scott RC, Desai N, Gutta P, Patil S. 2011 Seizure outcome in infantile spasms-A retrospective study. Epilepsia 52: 746-752.

Mullen SA, Scheffer IE. 2009. Translational research in epilepsy genetics: Sodium channels in man to interneuronopathy in mouse. Arch Neurol 66: 21-26.

Oakley JC, Kalume F, Yu FH, Scheuer T, Catterall WA. 2009. Temperature- and age-dependent seizures in a mouse model of severe myoclonic epilepsy in infancy. Proc Natl Acad Sci 106: 3994-3999.

O’Callaghan FJ, Lux AL, Darke K, Edwards SW, Hancock E, Johnson AL, Kennedy CR, Newton RW, Verity CM, Osborne JP. 2011. The effect of lead time to treatment and of age of onset on developmental outcome at 4 years in infantile spasms: Evidence from the United Kingdom Infantile Spasms Study. Epilepsia 52: 1359-1364.

Ogiwara I, Miyamoto H, Morita N, Atapour N, Mazaki E, Inoue I, Takeuchi T, Itohara S, Yanagawa Y, Obata K, et al. 2007. $\mathrm{Na}_{\mathrm{v}} 1.1$ localizes to axons of parvalbumin-positive inhibitory interneurons: A circuit basis for epileptic seizures in mice carrying an Scnla gene mutation. J Neurosci 27: 5903-5914.

Ogiwara I, Iwasato T, Miyamoto H, Iwata R, Yamagata T, Mazaki E, Yanagawa Y, Tamamaki N, Hensch TK, Itohara S, et al. 2013. $\mathrm{Na}_{\mathrm{v}} 1.1$ haploinsufficiency in excitatory neurons ameliorates seizure-associated sudden death in a mouse model of Dravet syndrome. Hum Mol Genet 22: 4784-4804.

Ojeda SR, Advis JP, Andrews WW. 1980a. Neuroendocrine control of the onset of puberty in the rat. Fed Proc 39: 2365-2371.

Ojeda SR, Andrews WW, Advis JP, White SS. 1980b. Recent advances in the endocrinology of puberty. Endocrine Rev 1: $228-257$.

Olivetti PR, Noebels JL. 2012. Interneuron, interrupted: Molecular pathogenesis of ARX mutations and X-linked infantile spasms. Curr Opin Neurobiol 22: 859-865.

Olivetti PR, Maheshwari A, Noebels JL. 2014. Neonatal estradiol stimulation prevents epilepsy in Arx model of X-linked infantile spasms syndrome. Sci Transl Med 6: $220 \mathrm{ra} 212$.

Ono T, Moshé SL, Galanopoulou AS. 2011. Carisbamate acutely suppresses spasms in a rat model of symptomatic infantile spasms. Epilepsia 52: 1678-1684.

Osborne JP, Lux AL, Edwards SW, Hancock E, Johnson AL, Kennedy CR, Newton RW, Verity CM, O'Callaghan FJ. 2010. The underlying etiology of infantile spasms (West syndrome): Information from the United Kingdom Infantile Spasms Study (UKISS) on contemporary causes and their classification. Epilepsia 51: 2168-2174.

Ostrach LH, Crabtree JW, Campbell BG, Chow KL. 1984 Effects of bicuculline-induced epileptiform activity on development of receptive field properties in striate cortex and lateral geniculate nucleus of the rabbit. Brain Res 317: $113-123$.

Otto JF, Singh NA, Dahle EJ, Leppert MF, Pappas CM, Pruess TH, Wilcox KS, White HS. 2009. Electroconvulsive seizure thresholds and kindling acquisition rates are altered in mouse models of human KCNQ2 and KCNQ3 mutations for benign familial neonatal convulsions. Epilepsia 50: 1752-1759.

Paciorkowski AR, Thio LL, Dobyns WB. 2011a. Genetic and biologic classification of infantile spasms. Pediatr Neurol 45: $355-367$.

Paciorkowski AR, Thio LL, Rosenfeld JA, Gajecka M, Gurnett CA, Kulkarni S, Chung WK, Marsh ED, Gentile M, Reggin JD, et al. 2011b. Copy number variants and infantile spasms: Evidence for abnormalities in ventral forebrain development and pathways of synaptic function. Eur J Hum Genet 19: 1238-1245.

Pan Y, Gerasimov MR, Kvist T, Wellendorph P, Madsen KK, Pera E, Lee H, Schousboe A, Chebib M, Brauner-Osborne $\mathrm{H}$, et al. 2012. (1S,3S)-3-amino-4-difluoromethylenyl1-cyclopentanoic acid (CPP-115), a potent $\gamma$-aminobutyric acid aminotransferase inactivator for the treatment of cocaine addiction. J Med Chem 55: 357-366.

Pellock JM, Hrachovy R, Shinnar S, Baram TZ, Bettis D, Dlugos DJ, Gaillard WD, Gibson PA, Holmes GL, Nord DR, et al. 2010. Infantile spasms: A U.S. consensus report. Epilepsia 51: 2175-2189.

Poirier K, Eisermann M, Caubel I, Kaminska A, Peudonnier S, Boddaert N, Saillour Y, Dulac O, Souville I, Beldjord C, et al. 2008. Combination of infantile spasms, non-epileptic seizures and complex movement disorder: A new case of ARX-related epilepsy. Epilepsy Res 80: 224-228.

Price MG, Yoo JW, Burgess DL, Deng F, Hrachovy RA, Frost JD Jr, Noebels JL. 2009. A triplet repeat expansion genetic mouse model of infantile spasms syndrome, Arx ${ }^{(\mathrm{GCG}) 10+7}$, with interneuronopathy, spasms in infan$\mathrm{cy}$, persistent seizures, and adult cognitive and behavioral impairment. J Neurosci 29: 8752-8763.

Pueschel SM, Louis S, McKnight P. 1991. Seizure disorders in Down syndrome. Arch Neurol 48: 318-320.

Pun RY, Rolle IJ, Lasarge CL, Hosford BE, Rosen JM, Uhl JD, Schmeltzer SN, Faulkner C, Bronson SL, Murphy BL, et al. 2012. Excessive activation of mTOR in postnatally generated granule cells is sufficient to cause epilepsy. Neuron 75: 1022-1034.

Raffo E, Coppola A, Ono T, Briggs SW, Galanopoulou AS. 2011. A pulse rapamycin therapy for infantile spasms and associated cognitive decline. Neurobiol Dis 43: $322-329$.

Reid CA, Leaw B, Richards KL, Richardson R, Wimmer V, Yu C, Hill-Yardin EL, Lerche H, Scheffer IE, Berkovic SF, et al. 2014. Reduced dendritic arborization and hyperexcitability of pyramidal neurons in a Scnlb-based model of Dravet syndrome. Brain 137: 1701-1715.

Riikonen R. 1982. A long-term follow-up study of 214 children with the syndrome of infantile spasms. Neuropediatrics 13: 14-23.

Riikonen R. 2001. Epidemiological data of West syndrome in Finland. Brain Dev 23: 539-541. 
Romano C, Tine A, Fazio G, Rizzo R, Colognola RM, Sorge G, Bergonzi P, Pavone L. 1990. Seizures in patients with trisomy 21. Am J Med Genet Supplement 7: 298-300.

Sanmaneechai O, Sogawa Y, Silver W, Ballaban-Gil K, Moshé SL, Shinnar S. 2013. Treatment outcomes of West syndrome in infants with Down syndrome. Pediatr Neurol 48: $42-47$.

Scantlebury MH, Gibbs SA, Foadjo B, Lema P, Psarropoulou C, Carmant L. 2005. Febrile seizures in the predisposed brain: A new model of temporal lobe epilepsy. Ann Neurol 58: $41-49$.

Scantlebury MH, Galanopoulou AS, Chudomelova L, Raffo E, Betancourth D, Moshé SL. 2010. A model of symptomatic infantile spasms syndrome. Neurobiol Dis 37: 604612.

Scheffer IE, Wallace RH, Phillips FL, Hewson P, Reardon K, Parasivam G, Stromme P, Berkovic SF, Gecz J, Mulley JC. 2002. X-linked myoclonic epilepsy with spasticity and intellectual disability: Mutation in the homeobox gene ARX. Neurology 59: 348-356.

Schutte RJ, Schutte SS, Algara J, Barragan EV, Gilligan J, Staber C, Savva YA, Smith MA, Reenan R, O’Dowd DK. 2014. Knock-in model of Dravet syndrome reveals a constitutive and conditional reduction in sodium current. $J$ Neurophysiol 112: 903-912.

Shatskikh TN, Raghavendra M, Zhao Q, Cui Z, Holmes GL. 2006. Electrical induction of spikes in the hippocampus impairs recognition capacity and spatial memory in rats. Epilepsy Behav 9: 549-556.

Shi XY, Zou LP, Yang G, Ding YX. 2012. Prenatal stress exposure hypothesis for infantile spasms. Med Hypotheses 78: 735-737.

Sidenvall R, Eeg-Olofsson O. 1995. Epidemiology of infantile spasms in Sweden. Epilepsia 36: 572-574.

Silverman RB. 2012. The 2011 E. B. Hershberg award for important discoveries in medicinally active substances: (1S,3S)-3-amino-4-difluoromethylenyl-1-cyclopentanoic acid (CPP-115), a GABA aminotransferase inactivator and new treatment for drug addiction and infantile spasms. J Med Chem 55: 567-575.

Silverstein F, Johnston MV. 1984. Cerebrospinal fluid monoamine metabolites in patients with infantile spasms. Neurology 34: 102-105.

Simonet JC, Sunnen CN, Wu J, Golden JA, Marsh ED. 2014 Conditional loss of Arx from the developing dorsal telencephalon results in behavioral phenotypes resembling mild human ARX mutations. Cereb Cortex doi: 10.1093/ cercor/bhu090.

Singh NA, Otto JF, Dahle EJ, Pappas C, Leslie JD, Vilaythong A, Noebels JL, White HS, Wilcox KS, Leppert MF. 2008 Mouse models of human KCNQ2 and KCNQ3 mutations for benign familial neonatal convulsions show seizures and neuronal plasticity without synaptic reorganization. J Physiol 586: 3405-3423.

Stafstrom CE, Sasaki-Adams DM. 2003. NMDA-induced seizures in developing rats cause long-term learning impairment and increased seizure susceptibility. Epilepsy Res 53: 129-137.

Stromme P, Mangelsdorf ME, Scheffer IE, Gecz J. 2002. Infantile spasms, dystonia, and other X-linked phenotypes caused by mutations in Aristaless related homeobox gene, ARX. Brain Dev 24: 266-268.
Sunnen CN, Brewster AL, Lugo JN, Vanegas F, Turcios E, Mukhi S, Parghi D, D'Arcangelo G, Anderson AE. 2011. Inhibition of the mammalian target of rapamycin blocks epilepsy progression in NS-Pten conditional knockout mice. Epilepsia 52: 2065-2075.

Tang B, Dutt K, Papale L, Rusconi R, Shankar A, Hunter J, Tufik S, Yu FH, Catterall WA, Mantegazza M, et al. 2009. A BAC transgenic mouse model reveals neuron subtype-specific effects of a generalized epilepsy with febrile seizures plus $\left(\mathrm{GEFS}^{+}\right)$mutation. Neurobiol Dis 35: 91-102.

Trotter SA, Kapur J, Anzivino MJ, Lee KS. 2006. GABAergic synaptic inhibition is reduced before seizure onset in a genetic model of cortical malformation. J Neurosci 26: 10756-10767.

Uhlmann EJ, Wong M, Baldwin RL, Bajenaru ML, Onda H, Kwiatkowski DJ, Yamada K, Gutmann DH. 2002. Astrocyte-specific TSC1 conditional knockout mice exhibit abnormal neuronal organization and seizures. Ann Neurol 52: 285-296.

Velisek L, Mares P. 1995. Age-dependent anticonvulsant action of clonazepam in the $N$-methyl-D-aspartate model of seizures. Pharmacol Biochem Behav 52: $291-$ 296.

Velisek L, Jehle K, Asche S, Veliskova J. 2007. Model of infantile spasms induced by $N$-methyl-D-aspartic acid in prenatally impaired brain. Ann Neurol 61: 109-119.

Vendrame M, Guilhoto LM, Loddenkemper T, Gregas M, Bourgeois BF, Kothare SV. 2012. Outcomes of epileptic spasms in patients aged less than 3 years: Singlecenter United States experience. Pediatr Neurol 46: 276-280.

* Vezzani A, Lang B, Aronica E. 2015. Immunity and inflammation in epilepsy. Cold Spring Harb Perspect Med doi: 10.1101/cshperspect.a022699.

Wang Y, Greenwood JS, Calcagnotto ME, Kirsch HE, Barbaro NM, Baraban SC. 2007. Neocortical hyperexcitability in a human case of tuberous sclerosis complex and mice lacking neuronal expression of TSC1. Ann Neurol 61: 139-152.

Wang YJ, Zhang Y, Liang XH, Yang G, Zou LP. 2012. Effects of adrenal dysfunction and high-dose adrenocorticotropic hormone on NMDA-induced spasm seizures in young Wistar rats. Epilepsy Res 100: 125-131.

Waymire KG, Mahuren JD, Jaje JM, Guilarte TR, Coburn SP, MacGregor GR. 1995. Mice lacking tissue non-specific alkaline phosphatase die from seizures due to defective metabolism of vitamin B-6. Nat Genet 11: $45-51$.

Weiss SR, Post RM, Gold PW, Chrousos G, Sullivan TL, Walker D, Pert A. 1986. CRF-induced seizures and behavior: Interaction with amygdala kindling. Brain Res 372: 345-351.

West WJ. 1841. On a peculiar form of infantile convulsions. Lancet Neurol 1: 724-725.

Wong M. 2013. Mammalian target of rapamycin (mTOR) pathways in neurological diseases. Biomed J 36: 40-50.

Yu FH, Mantegazza M, Westenbroek RE, Robbins CA, Kalume F, Burton KA, Spain WJ, McKnight GS, Scheuer T, Catterall WA. 2006. Reduced sodium current in GABAergic interneurons in a mouse model of severe 
A.S. Galanopoulou and S.L. Moshé

myoclonic epilepsy in infancy. Nat Neurosci 9: 11421149.

Yum MS, Chachua T, Veliskova J, Velisek L. 2012. Prenatal stress promotes development of spasms in infant rats. Epilepsia 53: e46-e49.

Zeng LH, Xu L, Gutmann DH, Wong M. 2008. Rapamycin prevents epilepsy in a mouse model of tuberous sclerosis complex. Ann Neurol 63: 444-453.

Zeng LH, Rensing NR, Zhang B, Gutmann DH, Gambello MJ, Wong M. 2011. Tsc2 gene inactivation causes a more severe epilepsy phenotype than Tscl inactivation in a mouse model of tuberous sclerosis complex. Hum $\mathrm{Mol}$ Genet 20: 445-454.
Zhou JL, Lenck-Santini PP, Zhao Q, Holmes GL. 2007a. Effect of interictal spikes on single-cell firing patterns in the hippocampus. Epilepsia 48: 720731.

Zhou JL, Shatskikh TN, Liu X, Holmes GL. 2007b. Impaired single cell firing and long-term potentiation parallels memory impairment following recurrent seizures. Eur J Neurosci 25: 3667-3677.

Zhou J, Blundell J, Ogawa S, Kwon CH, Zhang W, Sinton C, Powell CM, Parada LF. 2009. Pharmacological inhibition of mTORC1 suppresses anatomical, cellular, and behavioral abnormalities in neural-specific Pten knock-out mice. J Neurosci 29: 1773-1783. 


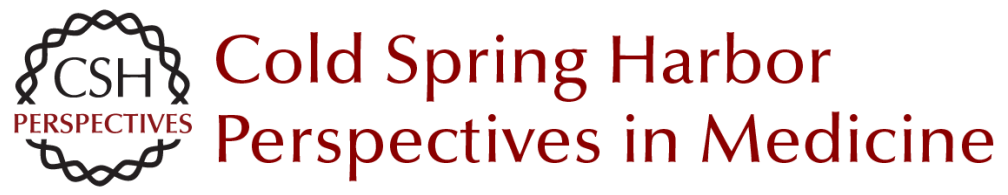

\title{
Neonatal and Infantile Epilepsy: Acquired and Genetic Models
}

\author{
Aristea S. Galanopoulou and Solomon L. Moshé \\ Cold Spring Harb Perspect Med 2016; doi: 10.1101/cshperspect.a022707 originally published online \\ December 4, 2015
}

\section{Subject Collection Epilepsy: The Biology of a Spectrum Disorder}

The Epilepsy Spectrum: Targeting Future Research Challenges

Gregory L. Holmes and Jeffrey L. Noebels

Role of Sodium Channels in Epilepsy

David I. Kaplan, Lori L. Isom and Steven Petrou

\section{Mechanisms of Action of Antiseizure Drugs and the Ketogenic Diet \\ Michael A. Rogawski, Wolfgang Löscher and Jong M. Rho}

Epilepsy and Autism

Ashura W. Buckley and Gregory L. Holmes

Immunity and Inflammation in Epilepsy Annamaria Vezzani, Bethan Lang and Eleonora Aronica

Hyperpolarization-Activated Cyclic

Nucleotide-Gated (HCN) Channels in Epilepsy Gary P. Brennan, Tallie Z. Baram and Nicholas P. Poolos

The Role of Calcium Channels in Epilepsy Sanjeev Rajakulendran and Michael G. Hanna

Interneuron Transplantation as a Treatment for Epilepsy

Robert F. Hunt and Scott C. Baraban

\section{Common Mechanisms Underlying Epileptogenesis and the Comorbidities of Epilepsy \\ Andrey Mazarati and Raman Sankar}

The Diathesis-Epilepsy Model: How Past Events Impact the Development of Epilepsy and Comorbidities

Christophe Bernard

Potassium Channels in Epilepsy Rüdiger Köhling and Jakob Wolfart

GABAergic Synchronization in Epilepsy Roustem Khazipov

Status Epilepticus Syndi Seinfeld, Howard P. Goodkin and Shlomo Shinnar

Neonatal and Infantile Epilepsy: Acquired and Genetic Models Aristea S. Galanopoulou and Solomon L. Moshé

Epigenetics and Epilepsy David C. Henshall and Katja Kobow

Microcircuits in Epilepsy: Heterogeneity and Hub Cells in Network Synchronization Anh Bui, Hannah K. Kim, Mattia Maroso, et al.

For additional articles in this collection, see http://perspectivesinmedicine.cshlp.org/cgi/collection/ 